\title{
DAMPAK PERCERAIAN DI INDONESIA : SYSTEMATIC LITERATURE REVIEW
}

\author{
Andria Pragholapati \\ Departemen Keperawatan, Fakultas Pendidikan Olah Raga Dan Kesehatan, Universitas Pendidikan \\ Indonesia \\ Email: andria.pragholapati@upi.edu
}

\begin{abstract}
Divorce in Indonesia is increasing every year. Divorce occurs because of many factors, and every individual is different. The effects of divorce on spouses, families, and children vary. The purpose of this study is to identify the impact of divorce in Indonesia in 2019-2020. The method used was a systematic literature review using the PRISMA protocol. The results obtained are 11 articles that fit the inclusion criteria and with critical appraisal tools from JBI. Discuss the causes of divorce in Indonesia, the impact of divorce that occurred in Indonesia, and how to overcome the impact of divorce in Indonesia.
\end{abstract}

Keyword: Divorce, Impact, Child, Adult, Partner, Family, Indonesia, Handling, Cause

\begin{abstract}
Abstrak
Perceraian di Indonesia meningkat tiap tahun. Perceraian terjadi karena banyak faktor, dan setiap individu berbeda-beda. Dampak perceraian terhadap pasangan, keluarga, dan anak sangat beragam. Tujuan penelitian ini untuk mengidentifikasi dampak perceraian di Indonesia pada tahun 2019-2020. Metode yang dilakukan menggunakan systematic literature review dengan menggunakan protokol PRISMA. Hasil didapatkan 11 artikel yang sesuai kriteria inklusi dan dengan critical apprasial tools dari JBI. Pembahasan penyebab perceraian di Indonesia, dampak perceraian yang terjadi di indonesia, dan cara mengatasi dampak perceraian di Indonesia.
\end{abstract}

Keyword: Perceraian, Dampak, Anak, Dewasa, Pasangan, Keluarga, Indonesia, Penanganan, Penyebab 


\section{Pendahuluan}

Law No. 1 of 1974 Article 38 explains marriages can be terminated because of death, divorce, and the court's decision. Furthermore, Article 39 explains that divorce can only be carried out in front of the Trial Court after the relevant Court tries and fails to reconcile the two parties, to divorce there must be enough reasons, that between the husband and wife will not be able to live in harmony as husband and wife, and the procedure the method of divorce before a court hearing is regulated in separate laws. Then divorce is permitted, although in principle this law complicates divorce (Pragholapati, 2020). This principle is an effort to reduce and reduce the number of divorces and that divorce is not used as a last alternative by husband and wife if there is a fight in the household.Divorce (divorce) is an eventof official separation between husband and wife and they are determined not to carry out their duties and obligations as husband and wife. They no longer live and live together, because there is no official bond. Those who have divorced but do not have children, separation does not have a psychological traumatic effect on children (Pragholapati, 2020).

Pragholapati, A. (2020, May 28) the role of nurses as providers of nursing care services, nurses have a duty to provide services to clients who experience mental health problems due to divorce. Nurses can provide psychoeducation and psychosocial interventions. Pragholapati, A. (2020) Depression most often occurs in people who do not have close interpersonal relationships or in those who are divorced or separated. Unmarried women have a lower tendency to suffer from depression than those who are married but this is inversely proportional for men. in divorced women, it is a very difficult time to get a job that suits their educational background, especially when the woman is divorced as a housewife. According to the subject in carrying out daily life feeling anxious and afraid of not being able to fulfill daily life with his children. Fear and anxiety can not meet the needs of their children's lives making the subject panic which results in increased emotions (Pragholapati, 2020).

Pragholapati, A. (2020) people with Psychiatric Problems, hereinafter abbreviated as ODMK are people who have physical, mental, social, growth and development, and / or quality of life problems so that they are at risk of developing mental illness. People with mental disorders, hereinafter abbreviated as ODGJ are people who experience disturbances in thoughts, behaviors, and feelings that are manifested in the form of a set of symptoms and / or changes in meaningful behavior, and can cause suffering and obstacles in carrying out people's functions as human beings. Pragholapati, A. (2020) The Coping Strategy 
is formed through a process of learning and remembering, which starts from the beginning of the onset of the stressor and when it starts to be realized the impact of the stressor. This ability to learn depends on external and internal conditions, so the role is not only how the environment forms the stressor but also the condition of the individual's temperament, perception, and cognition of the stressor.

\section{Metode}

Menggunakan metode Systematic Literature Review. Systematic Literature Review adalah merangkum hasil studi perawatan kesehatan yang dirancang dengan hati-hati (uji coba terkontrol) dan memberikan bukti tingkat tinggi tentang efektivitas intervensi perawatan kesehatan (Cochrane,n.d). Para penulis ulasan mengatur tentang tugas mereka dengan sangat sistematis mengikuti, langkah demi langkah, rencana lanjutan yang mencakup: cara studi yang ada ditemukan; bagaimana studi yang relevan dinilai berdasarkan kegunaannya dalam menjawab pertanyaan ulasan; bagaimana hasil dari studi terpisah disatukan untuk memberikan ukuran keseluruhan efektivitas (manfaat dan bahaya) - teknik statistik yang digunakan untuk menggabungkan hasil disebut meta-analisis (Cochrane, n.d). Kata kunci yang digunakan Dampak AND Perceraian OR Dampak Perceraian. Database pencarian yaitu menggunakan database Google Scholar. Kriteria inklusi yang digunakan tahun 2019-2020, penelitian di indonesia, jurnal, full text, menggunakan bahasa indonesia, jenis penelitian kualitatif dan literature review.

Tujuan dari tinjauan sistematis adalah untuk menilai secara menyeluruh, melalui prosedur yang ditetapkan, bukti terbaik tentang efek intervensi perawatan kesehatan atau perawatan dalam situasi perawatan kesehatan tertentu. Studi kesehatan pada umumnya dirancang untuk menilai manfaat, bukan bahaya, dari suatu intervensi. Studi umumnya memiliki periode waktu yang ditunjuk relatif singkat. Kerugian yang mungkin timbul dari suatu intervensi dapat diperkirakan terjadi lebih jarang dan dalam periode waktu yang lebih lama daripada yang dicakup oleh penelitian. Proses tinjauan didefinisikan dengan jelas, sebelum memulai tinjauan literatur yang sebenarnya, untuk meminimalkan asosiasi harapan efek dan sumber bias lainnya. Bias adalah 'kesalahan' sistematis atau kesalahan dalam penilaian dan keputusan yang dibuat yang mempengaruhi hasil penelitian atau ulasan. Bias berbeda dari 'efek plasebo', di mana peserta studi (atau penilai hasil) merasakan efek yang menguntungkan, atau membahayakan, dengan pengobatan yang tidak aktif. Metode khusus yang digunakan dalam ulasan secara hati-hati ditetapkan oleh The Cochrane Collaboration dan dijelaskan dalam setiap ulasan (Cochrane,n.d). 


\section{Hasil Penelitian}

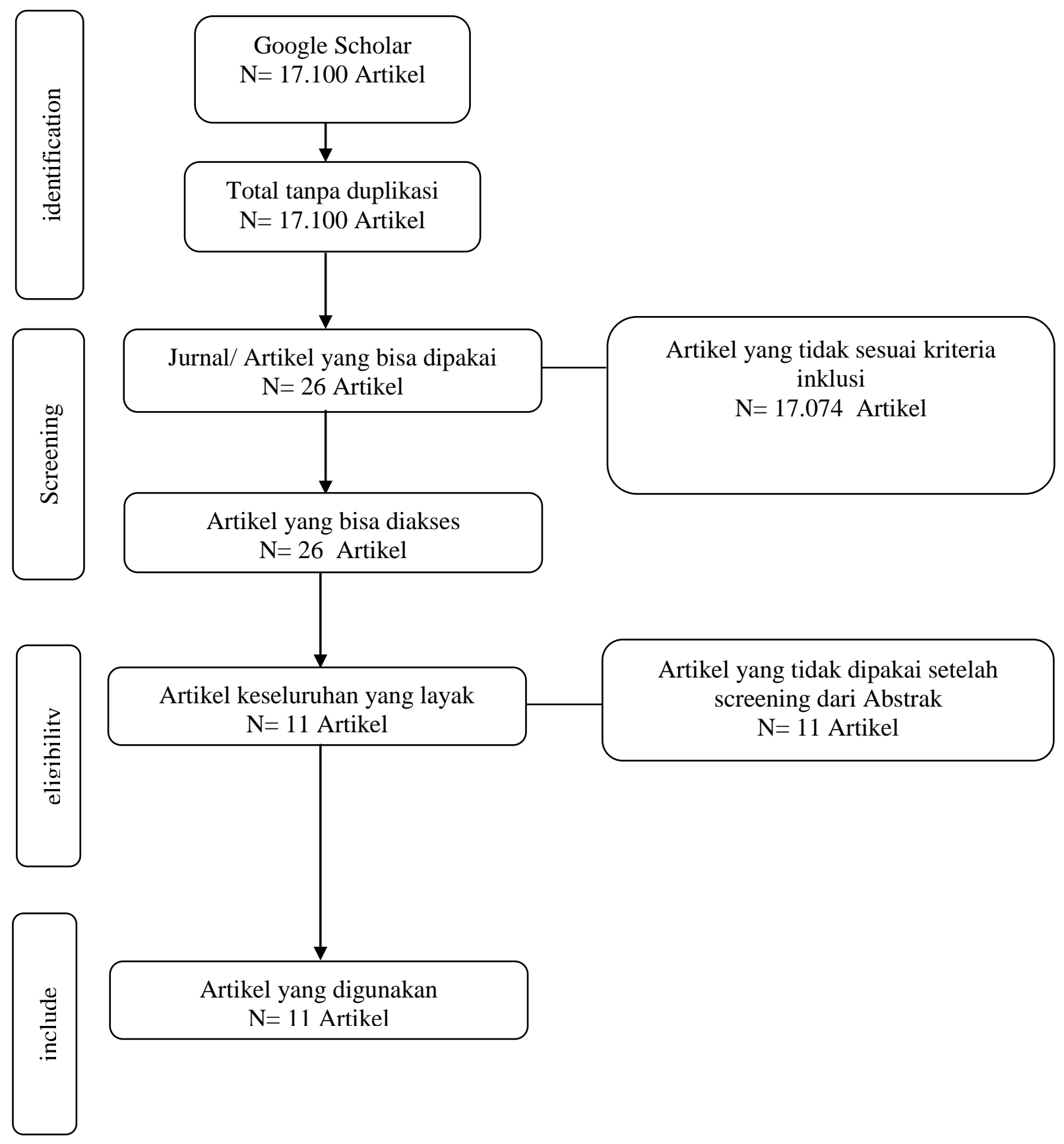


REVIEW ARTICLE

Juni 2020. Dampak Perceraian di Indonesia Systematic Literature Review

\begin{tabular}{|c|c|c|c|c|c|}
\hline NO & NAMA DAN TAHUN & METODE & Qual & $\mathbf{C S}$ & $\mathbf{L R}$ \\
\hline 1 & Andi Irma Ariani (2019) & Kualitatif tipe deskriptif, & $\mathbf{V}$ & & \\
\hline 2 & Magdalena Dewi Kusumawati (2020) & Kajian pustaka & & & $\mathbf{V}$ \\
\hline 3 & Fathur Rahim\& Hidjriah Fitriawati (2019) & $\begin{array}{l}\text { Deskriptif-kualitatif dengan } \\
\text { menggunakan metode studi kasus } \\
\text { (case study) }\end{array}$ & $\mathbf{V}$ & $\mathbf{V}$ & \\
\hline 4 & Sri Devi (2019) & $\begin{array}{l}\text { Kualitatif yang dituliskan } \\
\text { secaradeskrptif }\end{array}$ & $\mathbf{V}$ & & \\
\hline 5 & $\begin{array}{l}\text { Putri Erika Ramadhani , Hetty Krisnani } \\
\text { (2019) }\end{array}$ & $\begin{array}{l}\text { Metode dalam penulisan artikel } \\
\text { ini menggunakan studi literatur }\end{array}$ & & & $\mathbf{v}$ \\
\hline 6 & Harry Ferdinand Mone (2019) & $\begin{array}{l}\text { Fenomenologi dengan } \\
\text { menggunakan metode kualitatif } \\
\text { deskriptif. }\end{array}$ & $\mathbf{v}$ & & \\
\hline 7 & Ifawati Asri Mawaddah (2019) & $\begin{array}{l}\text { Penelitian ini menggunakan } \\
\text { pendekatan kulitatif deskriptif. } \\
\text { Dengan jenis Studi kasus. }\end{array}$ & $\mathbf{v}$ & $\mathbf{v}$ & \\
\hline 8 & Sri Endang Rayung Wulan (2019) & $\begin{array}{l}\text { Penelitian ini menggunakan } \\
\text { metode penelitian Normatif } \\
\text { dengan studi literatur }\end{array}$ & & & $\mathbf{v}$ \\
\hline 9 & $\begin{array}{l}\text { Santi Muardini, Alia Azmi, Fatmariza } \\
(2019)\end{array}$ & Metode kualitatif deskriftif & $\mathbf{v}$ & & \\
\hline 10 & $\begin{array}{l}\text { Nailatur Rosyada \& Siti Mutma'inah } \\
\text { (2019) }\end{array}$ & Penelitian kualitatif. & $\mathbf{v}$ & & \\
\hline 11 & $\begin{array}{l}\text { Tesalonika Liontinia Crossesa, Goretti } \\
\text { Maria Sindarti (2019) }\end{array}$ & $\begin{array}{l}\text { Penelitian ini adalah penelitian } \\
\text { deskriptif studi kasus dengan } 2 \\
\text { subjek penelitian }\end{array}$ & $\mathbf{v}$ & $\mathbf{v}$ & \\
\hline
\end{tabular}

Hasil penilaian studi systematic literature review dengan The JBI Critical Apprasial Tools

\begin{tabular}{|c|c|c|c|c|c|c|c|c|c|c|c|c|c|}
\hline NO & NAMA DAN & & & & & & $\mathbf{R} \mathbf{R}$ & TEI & & & & & HASIL \\
\hline & & 1 & 2 & 3 & 4 & 5 & 6 & 7 & 8 & 9 & $\mathbf{1 0}$ & 11 & \\
\hline 1 & Andi Irma Ariani (2019) & . & . & . & . & - & . & - & . & . & . & & $10 / 10$ \\
\hline 2 & $\begin{array}{l}\text { Magdalena Dewi } \\
\text { Kusumawati (2020) }\end{array}$ & - & - & - & - & - & - & - & - & - & - & - & $11 / 11$ \\
\hline 3 & $\begin{array}{l}\text { Fathur Rahim\& Hidjriah } \\
\text { Fitriawati (2019) }\end{array}$ & - & - & - & - & - & - & - & - & & & & $8 / 8$ \\
\hline 4 & Sri Devi (2019) & . & . & . & . & - & . & . & . & . & . & & $10 / 10$ \\
\hline 5 & $\begin{array}{l}\text { Putri Erika Ramadhani, } \\
\text { Hetty Krisnani (2019) }\end{array}$ & - & - & - & - & - & - & - & - & - & - & - & $11 / 11$ \\
\hline 6 & $\begin{array}{l}\text { Harry Ferdinand Mone } \\
\text { (2019) }\end{array}$ & - & - & - & - & - & - & - & - & - & - & & $10 / 10$ \\
\hline 7 & $\begin{array}{l}\text { Ifawati Asri Mawaddah } \\
\text { (2019) }\end{array}$ & - & - & - & - & - & - & - & - & & & & $8 / 8$ \\
\hline 8 & $\begin{array}{l}\text { Sri Endang Rayung Wulan } \\
\text { (2019) }\end{array}$ & - & - & - & - & - & - & - & - & - & - & - & $11 / 11$ \\
\hline 9 & $\begin{array}{l}\text { Santi Muardini, Alia } \\
\text { Azmi, Fatmariza (2019) }\end{array}$ & - & - & - & - & - & - & - & - & - & - & & $10 / 10$ \\
\hline 10 & $\begin{array}{l}\text { Nailatur Rosyada \& Siti } \\
\text { Mutma'inah (2019) }\end{array}$ & - & - & - & - & - & . & - & - & - & - & & $10 / 10$ \\
\hline 11 & $\begin{array}{l}\text { Tesalonika Liontinia } \\
\text { Crossesa, Goretti Maria } \\
\text { Sindarti (2019) }\end{array}$ & - & - & - & - & - & - & - & • & & & & $8 / 8$ \\
\hline
\end{tabular}




\section{Pembahasan}

Dalam penelitian ini menggunaan 11 artikel yang sesuai kriteria. 10 artikel tahun 2019 dan 1 artikel tahun 2020. 8 penelitian menggunakan metode penelitian kualitatif dan 3 penelitian menggunakan metode kajian pustaka/studi literatur.

\section{Penyebab Perceraian}

Ariani (2019) menyatakan bahwa perceraian dipicu berbagai macam sebab, diantaranya tidak harmonisnya hubungan suami isteri dari segi pemenuhan kebutuhan biologis, persoalan prinsip hidup yang berbeda, perbedaan penghasilan dalam peningkatan kesejahteraan hidup, adanya perselingkuhan, yakni Pria Idaman Lain (PIL) dan Wanita Idaman Lain (WIL) sebagai pihak ketiga perusak hubungan rumah tangga, perbuatan-perbuatan yang melanggar peran dan fungsinya masing-masing sebagai suami atau isteri, seperti Kekerasan Dalam Rumah Tangga (KDRT) dan adanya pengaruh dukungan sosial dari pihak luar. Begitu juga Devi (2019) faktor-faktor yang menyebabkan terjadinya Perceraian Di Dusun Bangkan Kabupaten Enrekang. Faktor tersebut antara lain, (a)Faktor internal (1)Faktor ekonomi, (2) Tidak adanya tanggung jawab, (3) Perselisihan dan kekerasan dalam rumah tangga (KDRT), (4)Perselingkuhan, (5) pernikahan tanpa cinta dan perjodohan orangtua. Mawaddah (2019) faktor penyebab perceraian suami istri di Desa Sulek Tlogosari Bondowoso adalah Kekerasan verbal, Ekonomi, Perselingkuhan, Kelalaian (tanggung jawab), Faktor Perselisihan campur tangan mertua.

\section{Dampak Perceraian}

Ariani (2019) Dampak perceraian orang tua dalam kehidupan sosial anak adalah kenakalan remaja, stress, phobia, sedih dan bingung menghadapi masalah yang ada, tidak mampu mengungkapkan perasaan, adanya perasaan kehilangan orang tua, daya imajinatif berkurang, kurang percaya terhadap pasangan (bagi yang dewasa), dan kurang percaya diri baik dilingkungan sekolah maupun tempat tinggalnya. Kusumawati (2020) dampak perceraian orang tua terhadap kondisi emosi anak ini dapat disimpulkan bahwa 1) kondisi emsoi sangat memperngaruhi kepribadian anak, 2) perceraian orang tua cenderung membawa dampak negatif yang lebih banyak terhadap kondisi emosi anak usia 6-12 tahun. Dilihat dari dampak negatif yang lebih dominan muncul terhadap anak jika orang tua bercerai, serta pentingnya emosi untuk menentukan kepribadian anak alangkah lebih baik orang tua memikirkan kembali keputusan untuk bercerai. Jika sudah terelanjur bercerai disarankan agar tetap menjalankan komunikasi dengan anak serta mantan pasangannya. Dan adanya partisipasi aktif dari keluarga dalam mengasuh anak bila perceraian benar-benar terjadi.

Fitriawati (2019) perceraian berdampak buruk bagi kelangsungan pendidikan anak. Devi (2019)Dampak yang ditimbulkannya adalah, (a) Dampak Fositif: (1)Perasaan lega setelah bercerai (b) Dampak Negatif (1) Anak hanya dekat dengan dengan salah satu orangtuanya. Krisnani (2019) dampak perceraian orang tua memang dapat memberikan dampak buruk bagi 


\section{REVIEW ARTICLE}

Juni 2020. Dampak Perceraian di Indonesia Systematic Literature Review

anak, baik fisik maupun psikologis anak. Mone (2019) : 1.) Perceraian (cerai hidup) membawa dampak yang negatif terhadap perkembangan psikososial dan prestasi belajar anak. Mawaddah (2019) dampak perceraian orang tua terhadap psikologi anak di Desa Sulek Tlogosari Bondowoso adalah Marah (Range) atau (Qalb), Sakit-sakitan (Psikomatis) atau (Nafs), Kesedihan (Sorrow) atau (Qalb), dan Tidak Percaya diri (Hipotimia) atau (Qalb).

Wulan (2019) Perceraian bukan jalan keluar yang baik untuk sebuah masalah di dalam keluarga. Karena bukan hanya suami dan istri yang menderita lahir dan bathin. Tetapi juga anak-anak hasil dari pernikahan tersebut. Keluarga adalah sangat penting bagi kehidupan anak, oleh sebab itu ayah maupun ibu jangan menjadikan perceraian jalan yang terbaik untuk penyenyelesaian masalah perkawinan. Karena perceraian merupakan hal yang sangat membuat menderita dan luka khusunya menyangkut psikologis anak. Fatmariza (2019) dampak perceraian pada perempuan usia muda terhadap kondisi sosial-ekonomi, pertama; cara janda muda dalam memenuhi kebutuhan ekonomi, kedua; orang yang membantu janda muda dalam memenuhi kebutuhan ekonomi. Dampak perceraian pada perempuan usia muda terhadap kondisi sosia-kemasyarakatan, pertama; pandangan janda muda terhadap dirinya sendiri, kedua; pandangan keluarga janda muda terhadap dirinya, ketiga; pandangan masyarakat terhadap janda muda, keempat; pandangan tokoh masyarakat terhadap janda muda, kelima; pandangan pemerintah terhadap janda muda, keenam; pandangan mantan suami terhadap mantan istri (janda muda), ketujuh; pandangan laki-laki yang masih lajang terhadap janda muda. Mutma'inah (2019) anak dari keluarga yang bercerai cenderung kurang baik disebabkan oleh kurang mendapat kasih sayang dari kedua orangtuanya. Gambaran kondisi emosi yang ditunjukkan anak yaitu anak tidak dapat mengendalikan diri pada saat marah, yaitu sering marah tidak jelas, membentak, sering menangis, dan membangkang.

\section{Cara Mengatasi Dampak Perceraian}

Mone (2019) 2.) Emosi atau perasaan anak sangat mempengaruhi aktivitas belajar di sekolah maupun di rumah, baik perasaan sedih, gembira, aman, marah, cemas, takut dan lain sebagainya; 3.) Adanya komunikasi antara orang tua dan anak setelah bercerai memperkecil pengaruh negatif dari perceraian. Kasih sayang dari keluarga kedua belah pihak dan bantuan guru dalam mengasuh anak korban perceraian di rumah dan sekolah, membuat anak kuat dan tegar menghadapi masalah keluarganya; dan 4.) Langkah pemulihan prestasi belajar yakni bersifat mendidik, misalnya memberikan pujian, hadiah, dan lain sebagainya yang mengandung nilai edukatif. Krisnani (2019) memberikan konseling. Crossesa \& Sindarti (2019) walaupun berada dalam keluarga yang broken home (orang tua bercerai), masih memiliki motivasi dalam belajarnya di sekolah. Perceraian orang tua tidak memengaruhi motivasi belajar mereka di sekolah, dapat dilihat dari hasil nelajar mereka. Motivasi kedua subjek penelitian tersebut diperoleh dari dukungan orang yang mereka sayangi, yaitu tante dan guru mereka yang sangat berperan sebagai pengganti orang tua mereka. Selain itu, subjek juga dapat menerima keadaannya meskipunkeluarganya Broken Home, ini karena kejadian perceraian yang terjadi sudah lama sejak mereka kecil, rentang kejadian yang lama ini membuat mereka sudah beradaptasi dengan keadaan dan dapat menerima keadaan yang mereka alami. Ada kalanya subjek merasakan sedih namuntidak berlarut larut dalam 


\title{
REVIEW ARTICLE
}

Juni 2020. Dampak Perceraian di Indonesia Systematic Literature Review

kesedihannya karena masih ada penyemangat hidupnya. Kedua subjek memiliki cara tersendiri untuk menghilangkan atau melupakan masalah yang terjadi dalam masalah keluargannya. Maka dari itu kedua subjek dapat merasa bebannya berkurang atau permasalahan yang ada di rumah dapat terlupakan dengan adanya orang-orang yang mendukungnya

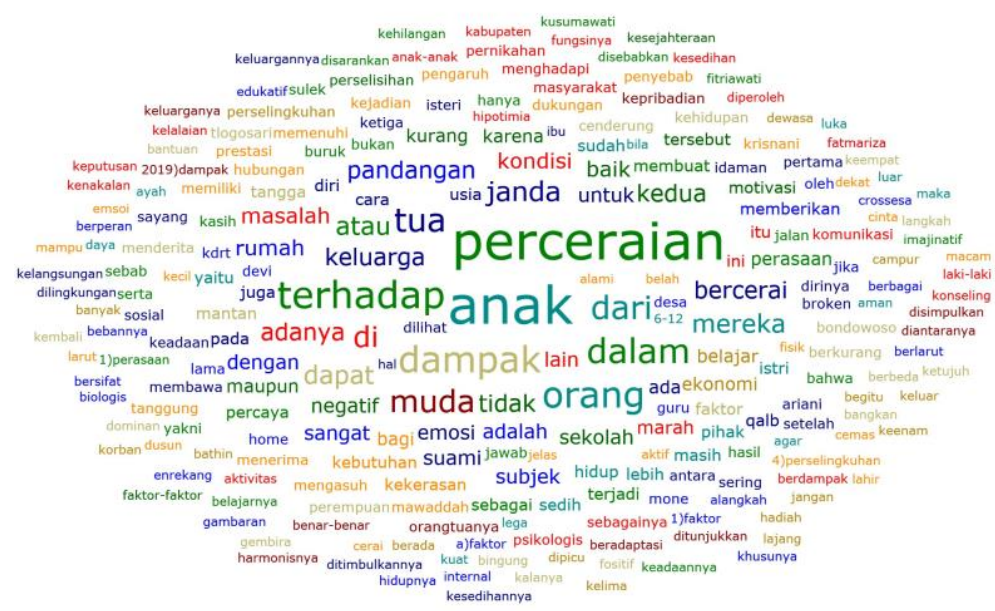

Gambar 1 Hasil Semua Word Cloud

\author{
perceraian \\ dampak \\ orang anak tua \\ terhadap \\ dalam dari ${ }_{\text {muda }}$
}

\section{Gambar 2 Hasil Seleksi Word Cloud}

Dampak perceraian mengenai usia muda dan usia tua. Dampak Perceraian lebih besar terhadap Anak dibandingkan Dewasa. 
REVIEW ARTICLE

Juni 2020. Dampak Perceraian di Indonesia Systematic Literature Review

\begin{tabular}{|c|c|c|c|c|c|c|}
\hline NO & $\begin{array}{c}\text { NAMA DAN } \\
\text { TAHUN }\end{array}$ & TUJUAN & METODE & SAMPEL & HASIL & KESIMPULAN \\
\hline 1 & $\begin{array}{l}\text { Andi Irma } \\
\text { Ariani (2019) }\end{array}$ & $\begin{array}{l}\text { Penelitian ini } \\
\text { bertujuan untuk } \\
\text { mengetahui, mengkaji, } \\
\text { dan menjelaskan (i) } \\
\text { Penyebab terjadinya } \\
\text { perceraian, (ii) } \\
\text { Dampak perceraian } \\
\text { orang tua dalam } \\
\text { kehidupan sosial anak. }\end{array}$ & $\begin{array}{l}\text { Penelitian ini merupakan jenis } \\
\text { penelitian kualitatif tipe deskriptif, data yang } \\
\text { dikumpulkan lebih mengambil bentuk kata-kata } \\
\text { atau gambar dari pada angka-angka sebagai alat } \\
\text { metode utamanya Kaelan, (2012: 12). Bogdan } \\
\text { dan Taylor dalam (Moleong, 2007:4) } \\
\text { mendefinisikan metodologi kualitatif sebagai } \\
\text { prosedur penelitian yang menghasilkan data } \\
\text { deskriptif berupa kata-kata tertulis atau lisan } \\
\text { dari orang-orang dan perilaku yang dapat } \\
\text { diamati. Menurut mereka, pendekatan ini } \\
\text { diarahkan pada latar dan individu tersebut secara } \\
\text { holistik (utuh). } \\
\text { Lokasi penelitian adalah di Kelurahan } \\
\text { Tetebatu Kecamatan Pallangga Kabupaten } \\
\text { Gowa. tentang dampak perceraian orang tua } \\
\text { dalam kehidupan sosial anak. Alasan pemilihan } \\
\text { lokasi penelitian di Kelurahan Tetebatu } \\
\text { Kecamatan Pallangga Kabupaten Gowa karena } \\
\text { melihat begitu banyak perkara antara pasangan } \\
\text { suami isteri sehingga menyebabkan perceraian } \\
\text { dan menimbulkan dampak bagi kehidupan sosial } \\
\text { anak dan menggunakan pendekatan studi kasus, } \\
\text { dimana menggunakan pendekatan studi kasus. }\end{array}$ & $\begin{array}{l}\text { Teknik purposive } \\
\text { sampling adalah } \\
\text { teknik penentuan } \\
\text { sampel dengan } \\
\text { pertimbangan } \\
\text { tertentu, dimana } \\
\text { peneliti } \\
\text { cenderung } \\
\text { memilih } \\
\text { informan secara } \\
\text { variatif } \\
\text { berdasarkan } \\
\text { (alasan), yang } \\
\text { jumlahnya } \\
\text { adalah } 30 \text { orang } \\
\text { dari } 7 \text { keluarga. } \\
\text { Informan } \\
\text { pendukung pada } \\
\text { subjek penelitian } \\
\text { ini adalah } \\
\text { pasangan suami } \\
\text { isteri yang } \\
\text { bercerai (usia 20- } \\
56 \text { tahun), anak } \\
\text { (usia 6-22 } \\
\text { tahun), orang } \\
\text { tua/mertua (usia } \\
60-70 \text { tahun). }\end{array}$ & $\begin{array}{l}\text { (i) Penyebab terjadinya perceraian } \\
\text { dalam kehidupan sosial anak adalah } \\
\text { hancurnya hubungan rumah tangga } \\
\text { pasangan suami isteri yang } \\
\text { menyebabkan perceraian dipicu } \\
\text { berbagai macam sebab, } \\
\text { diantaranya tidak harmonisnya } \\
\text { hubungan suami isteri dari segi } \\
\text { pemenuhan kebutuhan biologis, } \\
\text { persoalan prinsip hidup yang } \\
\text { berbeda, perbedaan penghasilan } \\
\text { dalam peningkatan kesejahteraan } \\
\text { hidup, adanya perselingkuhan, yakni } \\
\text { Pria Idaman Lain (PIL) dan Wanita } \\
\text { Idaman Lain (WIL) sebagai pihak } \\
\text { ketiga perusak hubungan rumah } \\
\text { tangga, perbuatan-perbuatan yang } \\
\text { melanggar peran dan fungsinya } \\
\text { masing-masing sebagai suami atau } \\
\text { isteri, seperti Kekerasan Dalam } \\
\text { Rumah Tangga (KDRT) dan adanya } \\
\text { pengaruh dukungan sosial dari pihak } \\
\text { luar. (ii) Dampak perceraian orang } \\
\text { tua dalam kehidupan sosial anak } \\
\text { adalah kenakalan remaja, stress, } \\
\text { phobia, sedih dan bingung } \\
\text { menghadapi masalah yang ada, tidak } \\
\text { mampu mengungkapkan perasaan, } \\
\text { adanya perasaan kehilangan orang } \\
\text { tua, daya imajinatif berkurang, } \\
\text { kurang percaya terhadap pasangan } \\
\text { (bagi yang dewasa), dan kurang } \\
\text { percaya diri baik dilingkungan } \\
\text { sekolah maupun tempat tinggalnya. }\end{array}$ & $\begin{array}{l}\text { Kesimpulan } \\
\text { dalam penelitian } \\
\text { adalah (1) } \\
\text { Penyebab } \\
\text { terjadinya } \\
\text { perceraian di } \\
\text { Kelurahan } \\
\text { Tetebatu } \\
\text { Kecamatan } \\
\text { Pallangga } \\
\text { Kabupaten } \\
\text { Gowa adalah } \\
\text { hancurnya } \\
\text { hubungan rumah } \\
\text { tangga } \\
\text { pasangan suami } \\
\text { isteri yang } \\
\text { menyebabkan } \\
\text { perceraian dipicu } \\
\text { berbagai macam } \\
\text { sebab, } \\
\text { diantaranya tidak } \\
\text { harmonisnya } \\
\text { hubungan suami } \\
\text { isteri dari segi } \\
\text { pemenuhan } \\
\text { kebutuhan } \\
\text { biologis, } \\
\text { persoalan prinsip } \\
\text { hidup yang } \\
\text { berbeda, } \\
\text { perbedaan } \\
\text { penghasilan } \\
\text { dalam }\end{array}$ \\
\hline
\end{tabular}




\section{REVIEW ARTICLE}

Juni 2020. Dampak Perceraian di Indonesia Systematic Literature Review

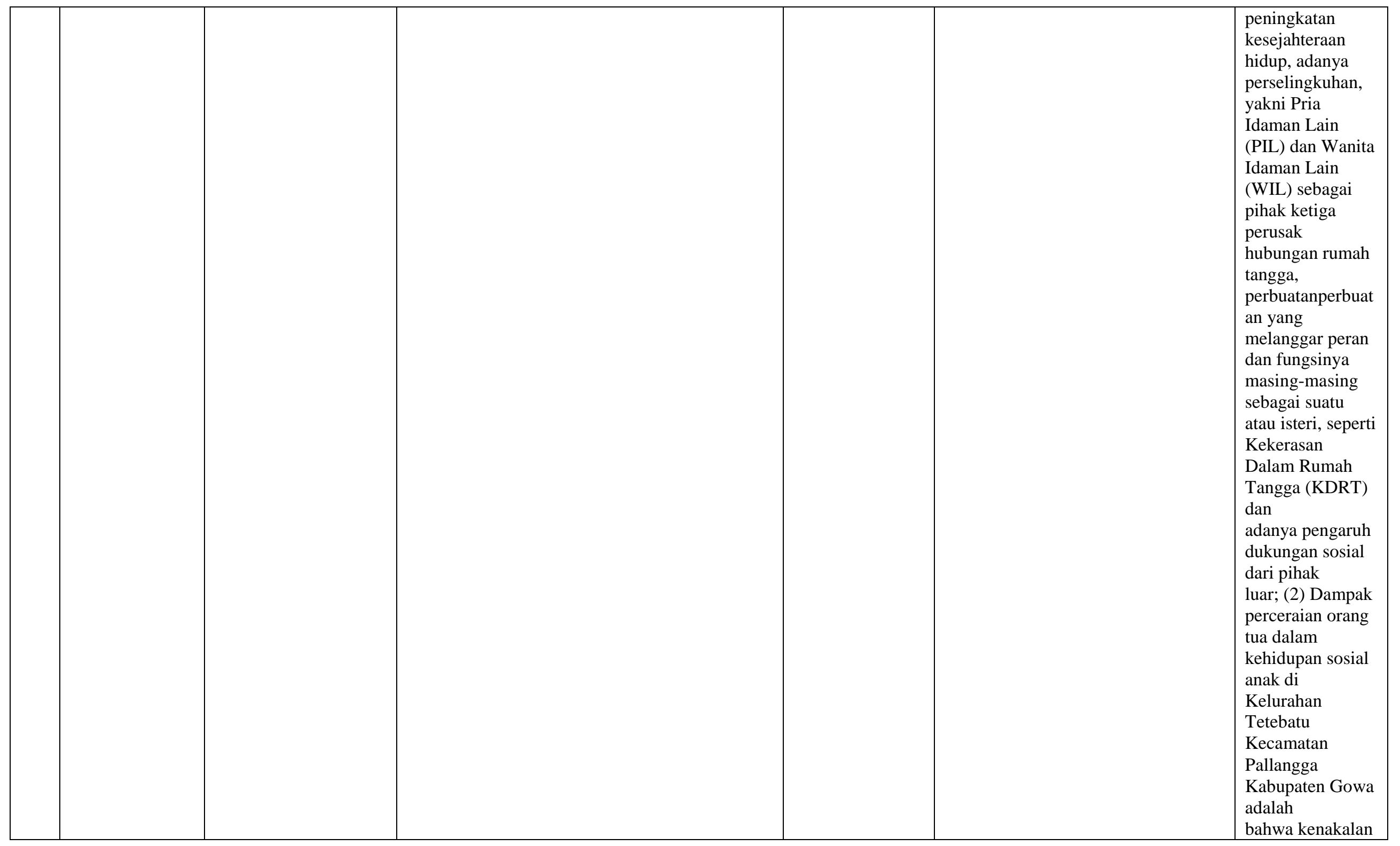




\section{REVIEW ARTICLE}

Juni 2020. Dampak Perceraian di Indonesia Systematic Literature Review

\begin{tabular}{|c|c|c|c|c|c|}
\hline & & & & & $\begin{array}{l}\text { remaja, stress, } \\
\text { phobia, sedih } \\
\text { dan bingung } \\
\text { menghadapi } \\
\text { masalah yang } \\
\text { ada, } \\
\text { tidak mampu } \\
\text { mengungkapkan } \\
\text { perasaan, adanya } \\
\text { perasaan } \\
\text { kehilangan orang } \\
\text { tua, daya } \\
\text { imajinatif } \\
\text { berkurang, } \\
\text { kurang percaya } \\
\text { terhadap } \\
\text { pasangan } \\
\text { (bagi yang } \\
\text { dewasa), dan } \\
\text { kurang percaya } \\
\text { diri } \\
\text { baik } \\
\text { dilingkungan } \\
\text { sekolah maupun } \\
\text { tempat } \\
\text { tinggalnya. }\end{array}$ \\
\hline 2 & $\begin{array}{l}\text { Magdalena } \\
\text { Dewi } \\
\text { Kusumawati } \\
(2020)\end{array}$ & $\begin{array}{l}\text { Penelitian ini } \\
\text { bertujuan untuk } \\
\text { mengetahui dampak } \\
\text { perceraian orang tua } \\
\text { terhadap kondisi } \\
\text { emosi anak usia 6-12 } \\
\text { tahun sehingga } \\
\text { peneliti dapat melihat } \\
\text { dampak positif dan } \\
\text { dampak negatif bagi } \\
\text { kondisi emosi anak } \\
\text { yang diakibatkan oleh } \\
\text { perceraian orang tua. }\end{array}$ & $\begin{array}{l}\text { Teknik pengumpulan data dari penelitian ini } \\
\text { adalah kajian pustaka, yaitu mengumpulkan } \\
\text { sumber-sumber dan jurnal yang berkaitan } \\
\text { dengan dampak perceraian orang tua terhadap } \\
\text { kondisi emosi anak usia 6-12 tahun. }\end{array}$ & $\begin{array}{l}\text { Teknik analisis } \\
\text { data yang } \\
\text { digunakan dalam } \\
\text { penelitian ini } \\
\text { adalah analisis } \\
\text { data model Miles } \\
\text { dan Huberman } \\
\text { yaitu tringaluasi } \\
\text { data yang terdiri } \\
\text { dari reduksi } \\
\text { data (data } \\
\text { reduction), } \\
\text { display data }\end{array}$ & $\begin{array}{l}\text { Berdasarkan } \\
\text { penelitian kajian } \\
\text { pustaka tentang } \\
\text { dampak } \\
\text { perceraian } \\
\text { orang tua } \\
\text { terhadap } \\
\text { kondisi emosi } \\
\text { anak ini dapat } \\
\text { disimpulkan } \\
\text { bahwa 1) } \\
\text { kondisi emsoi } \\
\text { sangat }\end{array}$ \\
\hline
\end{tabular}




\section{REVIEW ARTICLE}

Juni 2020. Dampak Perceraian di Indonesia Systematic Literature Review

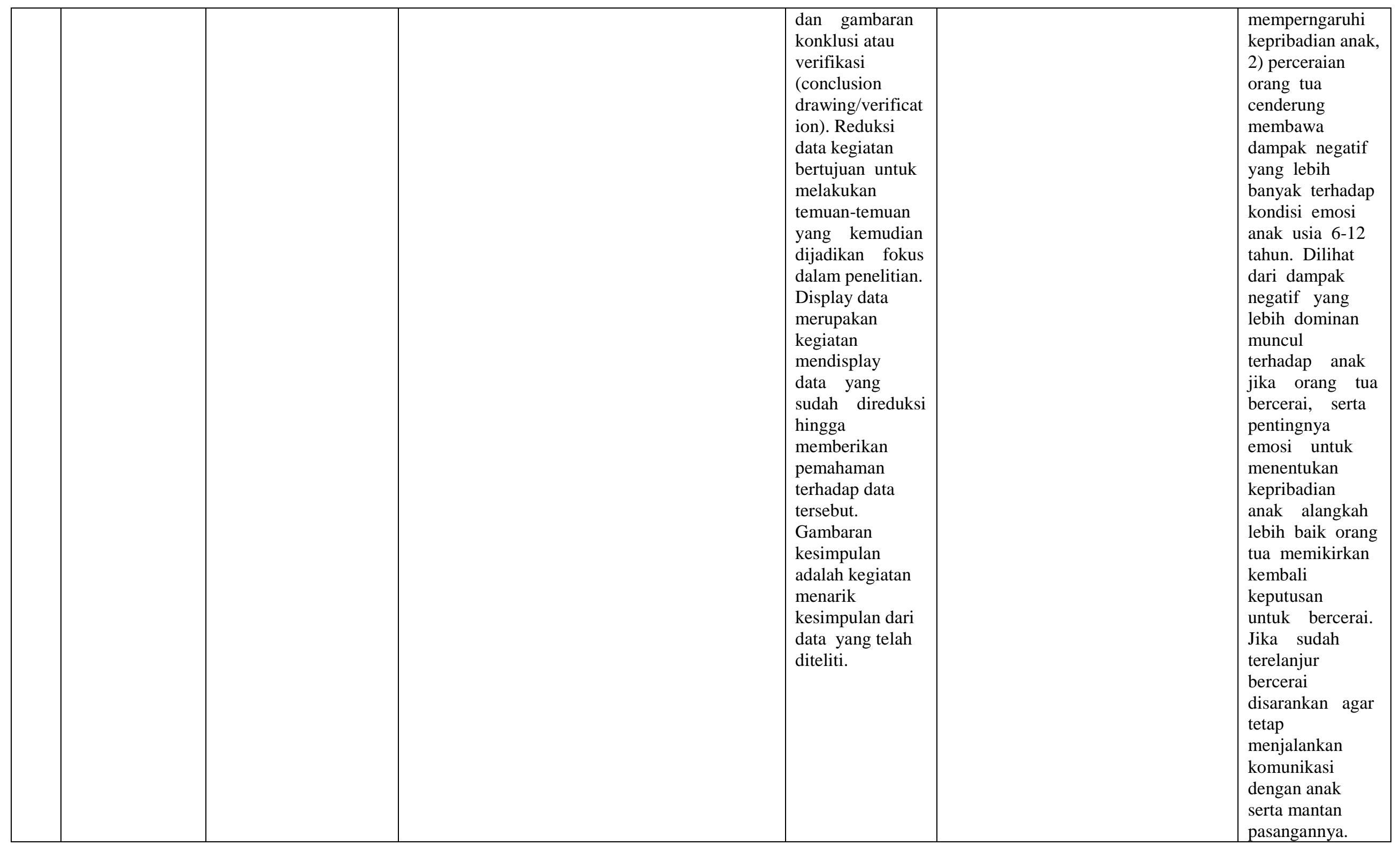




\section{REVIEW ARTICLE}

Juni 2020. Dampak Perceraian di Indonesia Systematic Literature Review

\begin{tabular}{|c|c|c|c|c|c|c|}
\hline & & & & & & $\begin{array}{l}\text { Dan adanya } \\
\text { partisipasi aktif } \\
\text { dari keluarga } \\
\text { dalam mengasuh } \\
\text { anak bila } \\
\text { perceraian benar- } \\
\text { benar terjadi. }\end{array}$ \\
\hline 3 & $\begin{array}{l}\text { Fathur Rahim\& } \\
\text { Hidjriah } \\
\text { Fitriawati } \\
(2019)\end{array}$ & $\begin{array}{l}\text { Penelitian ini } \\
\text { bertujuan untuk } \\
\text { mendapatkan } \\
\text { gambaran mengenai } \\
\text { gejala- gejala yang } \\
\text { timbul sebagai } \\
\text { dampak perceraian } \\
\text { yang memiliki } \\
\text { hubungan dengan } \\
\text { kelangsungan } \\
\text { pendidikan anak. }\end{array}$ & $\begin{array}{l}\text { Data- data diperoleh dengan mengamati secara } \\
\text { langsung, dan mewawancarai anak-anak pasca } \\
\text { perceraian, keluarga, tetangga, teman dan pihak } \\
\text { sekolah tempat dimana anak tersebut sekolah } \\
\text { untuk mendapatkan informasi yang lebih } \\
\text { komprehensif. Data hasil penelitian tersebut } \\
\text { kemudian dianalisis secara deskriptif-kualitatif } \\
\text { dengan menggunakan metode studi kasus } \\
\underline{\text { case study) }}\end{array}$ & & $\begin{array}{l}\text { menghasilkan kesumpulan bahwa } \\
\text { secara umum perceraian berdampak } \\
\text { buruk bagi kelangsungan pendidikan } \\
\text { anak. }\end{array}$ & $\begin{array}{l}\text { Perceraian } \\
\text { berdampak buruk } \\
\text { terhadap } \\
\text { kelangsungan } \\
\text { pendidikan anak } \\
\text { di Pangkung } \\
\text { Buluh, } \\
\text { Kabupaten } \\
\text { Jembrana, } \\
\text { Provinsi Bali, } \\
\text { yaitu putus } \\
\text { sekolah. } \\
\text { Sementara anak- } \\
\text { anak yang masih } \\
\text { tetap dapat } \\
\text { melanjutkan } \\
\text { sekolah } \\
\text { dikarenakan } \\
\text { adanya } \\
\text { keterlibatan } \\
\text { faktor eksternal } \\
\text { dalam bentuk } \\
\text { dukungan baik } \\
\text { dari lingkungan } \\
\text { keluarga maupun } \\
\text { teman bergaul. }\end{array}$ \\
\hline 4 & Sri Devi (2019) & $\begin{array}{l}\text { Penelitian ini berujuan } \\
\text { untuk mengetahui :(1) } \\
\text { Bagaimana Proses } \\
\text { Perceraian Di Dusun } \\
\text { Bangkan } \\
\text { KabupatenEnrekang.(2 }\end{array}$ & $\begin{array}{l}\text { Dalampenelitian inimenggunakanjenispenelitian } \\
\text { kualitatif } \\
\text { yangdituliskansecaradeskrptif.tekhnikpengum } \\
\text { pulandatadilakukandenganmetodeobervasi, } \\
\text { wawancaradandokumentasi. }\end{array}$ & $\begin{array}{l}\text { Penelitianinimeli } \\
\text { batkan12orang } \\
\text { informan. }\end{array}$ & $\begin{array}{l}\text { berdasarkanhasil } \\
\text { penelitiandilapangan,menunjukkanba } \\
\text { hwaprosesperceraianDiDususn } \\
\text { Bangkan Kabupaten Enrekang } \\
\text { terjadibegitusajadanbahkan } \\
\text { sebagianmasyarakatnyayangberceraij }\end{array}$ & $\begin{array}{l}\text { Berdasarkan } \\
\text { hasil dari } \\
\text { penelitian } \\
\text { tentang } \\
\text { Perceraian } \\
\text { (Studi Kasus Di }\end{array}$ \\
\hline
\end{tabular}




\section{REVIEW ARTICLE}

Juni 2020. Dampak Perceraian di Indonesia Systematic Literature Review

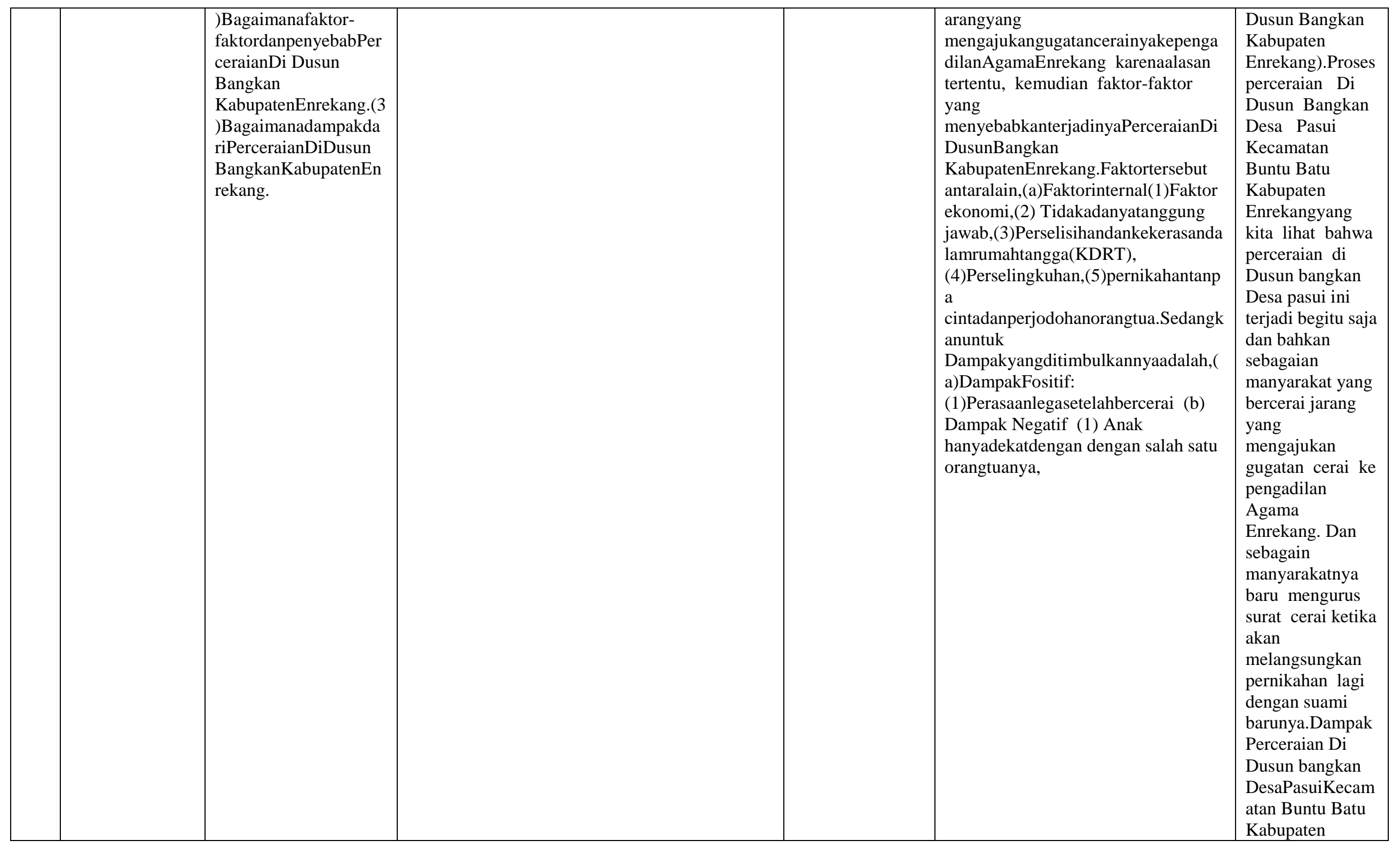




\section{REVIEW ARTICLE}

Juni 2020. Dampak Perceraian di Indonesia Systematic Literature Review

\begin{tabular}{|c|c|c|c|c|}
\hline & & & & $\begin{array}{l}\text { Enrekang,yaitu } \\
\text { adanya perasaan } \\
\text { legatelah } \\
\text { bercerai, } \\
\text { adausaha } \\
\text { menyesuaikan } \\
\text { diri, dan anak } \\
\text { hanyadekat } \\
\text { dengan salah satu } \\
\text { orangtuanya.Refe } \\
\text { rensiAbdul Jasim } \\
\text { Ishaq, n.d. } \\
\text { Kepala Desa } \\
\text { Pasui.Abdullah, } \\
\text { A.G., 1994. } \\
\text { Pengantar } \\
\text { Kompilasi } \\
\text { Hukum Islam } \\
\text { dalam Tata } \\
\text { Hukum } \\
\text { Indonesia. Gema } \\
\text { Insani Press. }\end{array}$ \\
\hline 5 & $\begin{array}{l}\text { Putri Erika } \\
\text { Ramadhani1 } \\
\text { Hetty Krisnani } \\
(2019)\end{array}$ & $\begin{array}{l}\text { Metode dalam penulisan artikel ini } \\
\text { menggunakan studi literatur. Studi literatur } \\
\text { yaitu data sekunder yang dilakukan dengan } \\
\text { diawali mencari kajian kepustakaan dari } \\
\text { berbagai literatur seperti buku, jurnal ilmiah, } \\
\text { artikel, ataupun hasil penelitian sejenis yang } \\
\text { telah dipublikasikan mengenai dampak } \\
\text { perceraian orang tua terhadap anak remaja. }\end{array}$ & $\begin{array}{l}\text { Hingga saat ini dampak perceraian } \\
\text { orang tua memang dapat memberikan } \\
\text { dampak buruk bagi anak, baik fisik } \\
\text { maupun psikologis anak. Sehingga } \\
\text { perceraian memang perlu } \\
\text { dipertimbangkan matang-matang, } \\
\text { dan orang tua harus bisa memberikan } \\
\text { pengertian yang baik kepada anak } \\
\text { sehingga dapat mengurangi dan } \\
\text { mengatasi dampak buruk pada anak } \\
\text { pada saat perceraian terjadi. Tetapi } \\
\text { fungsi keluarga untuk memberikan } \\
\text { pengertian dan perhatian pada } \\
\text { anak/remaja ternyata tidak berfungsi } \\
\text { dalam kaitannya dengan kasus } \\
\text { perceraian. Untuk mengatasi } \\
\text { perlakuan salah tersebut, maka dalam }\end{array}$ & $\begin{array}{l}\text { Hingga saat ini } \\
\text { dampak } \\
\text { perceraian orang } \\
\text { tua } \\
\text { memang dapat } \\
\text { memberikan } \\
\text { dampak buruk } \\
\text { bagi } \\
\text { anak, baik fisik } \\
\text { maupun } \\
\text { psikologis anak. } \\
\text { Sehingga } \\
\text { perceraian } \\
\text { memang perlu } \\
\text { dipertimbangkan } \\
\text { matang-matang, } \\
\text { dan orang tua }\end{array}$ \\
\hline
\end{tabular}




\section{REVIEW ARTICLE}

Juni 2020. Dampak Perceraian di Indonesia Systematic Literature Review

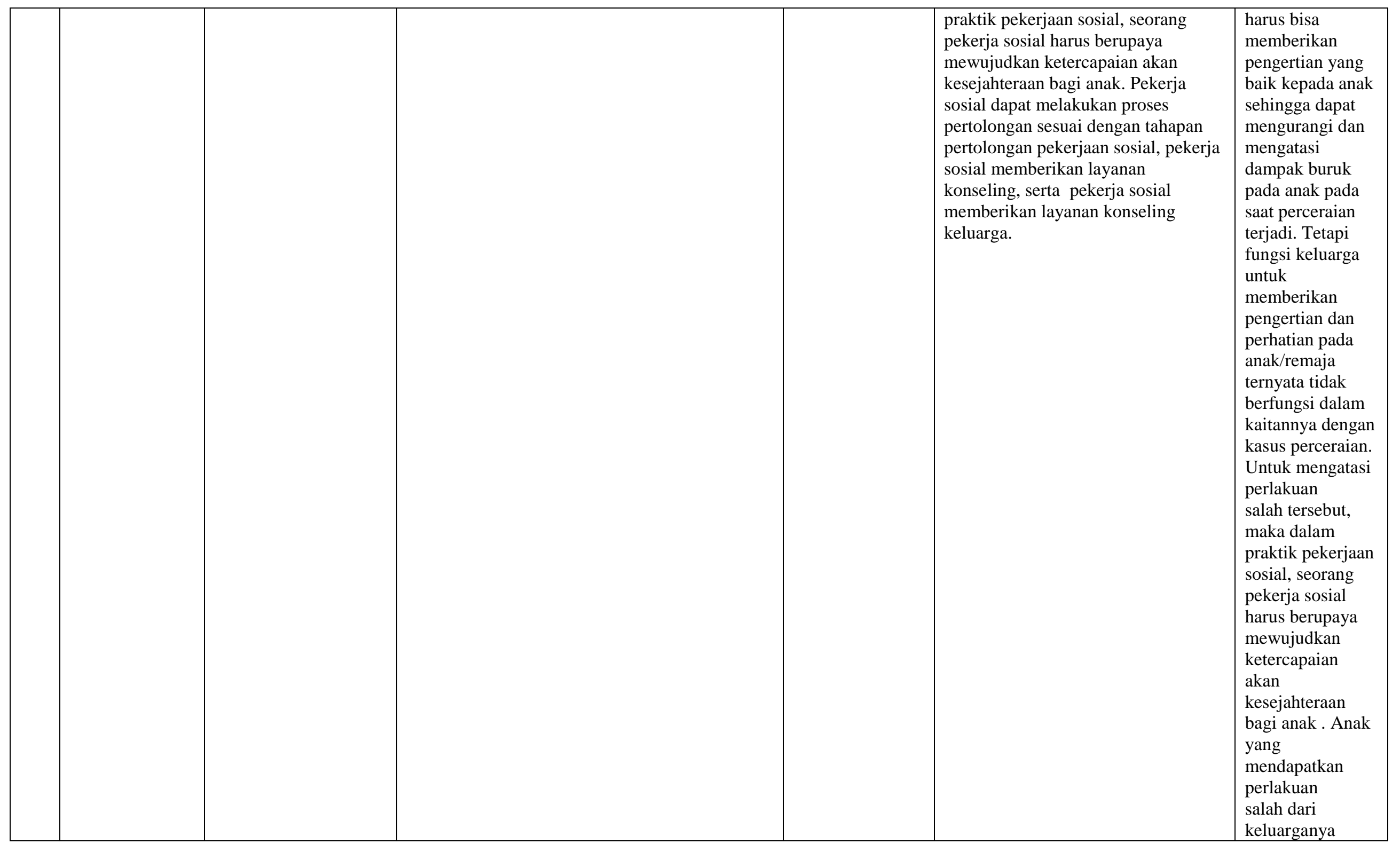




\section{REVIEW ARTICLE}

Juni 2020. Dampak Perceraian di Indonesia Systematic Literature Review

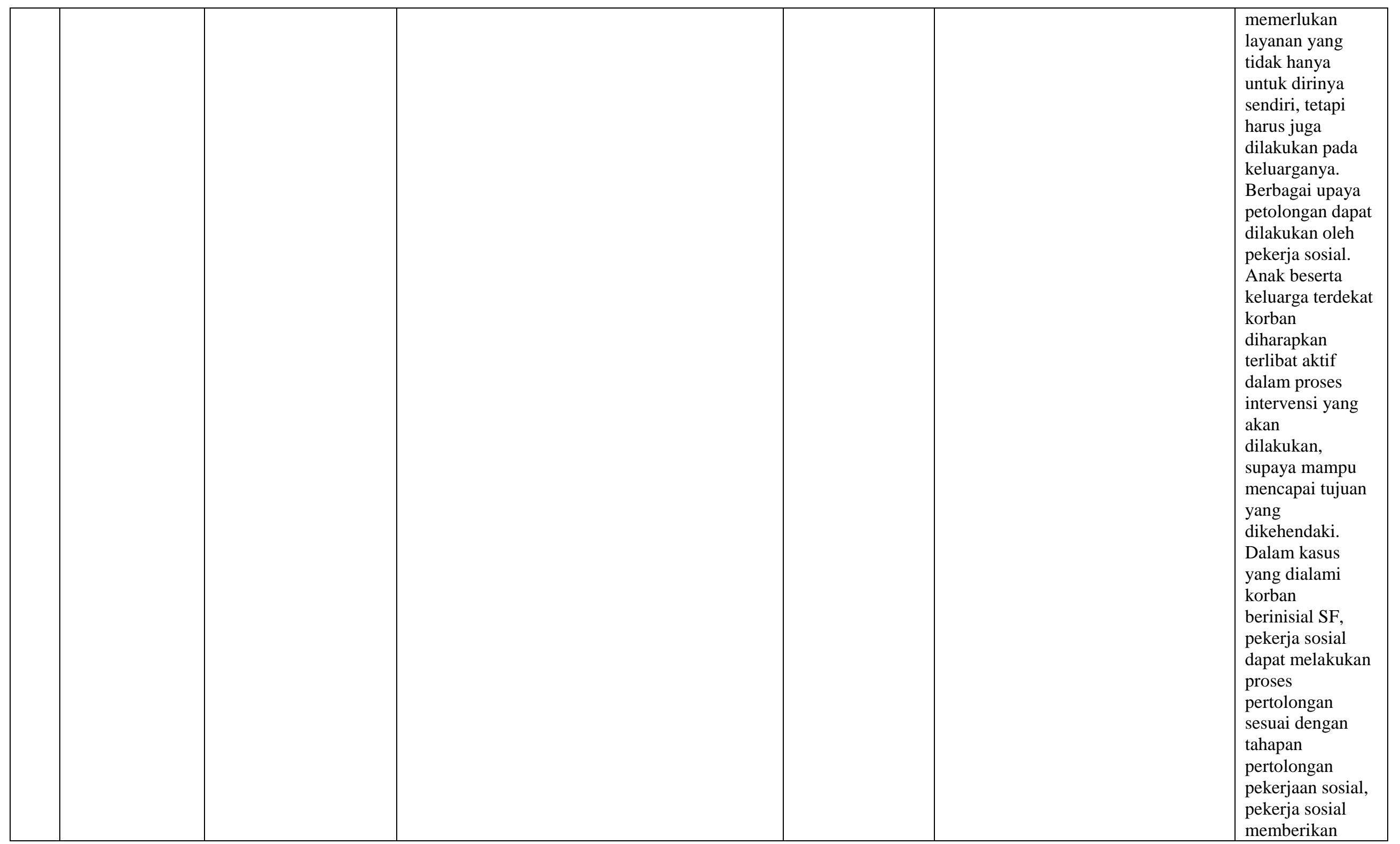




\section{REVIEW ARTICLE}

Juni 2020. Dampak Perceraian di Indonesia Systematic Literature Review

\begin{tabular}{|c|c|c|c|c|c|c|}
\hline & & & & & & $\begin{array}{l}\text { layanan } \\
\text { konseling, serta } \\
\text { pekerja } \\
\text { sosial } \\
\text { memberikan } \\
\text { layanan } \\
\text { konseling } \\
\text { keluarga. } \\
\text { Semua upaya } \\
\text { tersebut } \\
\text { melibatkan } \\
\text { berbagai pihak } \\
\text { untuk turut serta } \\
\text { aktif antara lain } \\
\text { klien, keluarga, } \\
\text { masyarakat, dan } \\
\text { pekerja sosial. }\end{array}$ \\
\hline 6 & $\begin{array}{l}\text { Harry Ferdinand } \\
\text { Mone (2019) }\end{array}$ & $\begin{array}{l}\text { Tujuan yang dicapai } \\
\text { pada penelitan ini } \\
\text { mendeskripsikan: 1.) } \\
\text { Dampak perceraian } \\
\text { orang tua terhadap } \\
\text { perkembangan } \\
\text { psikososial anak; 2.) } \\
\text { Dampak perceraian } \\
\text { orang tua terhadap } \\
\text { prestasi belajar anak; } \\
\text { 3.) Langkah-langkah } \\
\text { pemulihan } \\
\text { perkembangan } \\
\text { psikososial anak } \\
\text { akibat perceraian } \\
\text { orang tua; dan 4) } \\
\text { langkah-langkah } \\
\text { pemulihan prestasi } \\
\text { belajar anak akibat } \\
\text { perceraian orang tua. } \\
\text { Penelitian ini berlokasi } \\
\text { di kecamatan Oebobo, }\end{array}$ & $\begin{array}{l}\text { Penelitian ini menggunakan pendekatan } \\
\text { fenomenologi dengan menggunakan metode } \\
\text { kualitatif deskriptif. }\end{array}$ & $\begin{array}{l}\text { Subjek dalam } \\
\text { penelitian ini } \\
\text { adalah pasangan } \\
\text { yang bercerai } \\
\text { dengan orang, } \\
\text { keluarga, } \\
\text { tetangga, anak, } \\
\text { dan guru wali } \\
\text { kelas, yang } \\
\text { berjumlah } 35 \\
\text { orang. }\end{array}$ & $\begin{array}{l}\text { Hasil penelitian yang diperoleh: 1.) } \\
\text { Perceraian (cerai hidup) membawa } \\
\text { dampak yang negatif terhadap } \\
\text { perkembangan psikososial dan } \\
\text { prestasi belajar anak; } 2 \text {.) Emosi atau } \\
\text { perasaan anak sangat mempengaruhi } \\
\text { aktivitas belajar di sekolah maupun } \\
\text { di rumah, baik perasaan sedih, } \\
\text { gembira, aman, marah, cemas, takut } \\
\text { dan lain sebagainya; } 3 \text {.) Adanya } \\
\text { komunikasi antara orang tua dan } \\
\text { anak setelah bercerai memperkecil } \\
\text { pengaruh negatif dari perceraian. } \\
\text { Kasih sayang dari keluarga kedua } \\
\text { belah pihak dan bantuan guru dalam } \\
\text { mengasuh anak korban perceraian di } \\
\text { rumah dan sekolah, membuat anak } \\
\text { kuat dan tegar menghadapi masalah } \\
\text { keluarganya; dan 4.) Langkah } \\
\text { pemulihan prestasi belajar yakni } \\
\text { bersifat mendidik, misalnya } \\
\text { memberikan pujian, hadiah, dan lain }\end{array}$ & $\begin{array}{l}\text { Kesimpulan pada } \\
\text { penelitian ini } \\
\text { adalah: } 1 . \text { ) } \\
\text { Perceraian (cerai } \\
\text { hidup) membawa } \\
\text { dampak yang } \\
\text { negatif terhadap } \\
\text { perkembangan } \\
\text { psikososial dan } \\
\text { prestasi belajar } \\
\text { anak; 2) Emosi } \\
\text { atau perasaan } \\
\text { anak sangat } \\
\text { mempengaruhi } \\
\text { aktivitas belajar } \\
\text { di sekolah } \\
\text { maupun di } \\
\text { rumah, baik } \\
\text { perasaan sedih, } \\
\text { gembira, aman, } \\
\text { marah, cemas, } \\
\text { takut dan lain }\end{array}$ \\
\hline
\end{tabular}




\section{REVIEW ARTICLE}

Juni 2020. Dampak Perceraian di Indonesia Systematic Literature Review

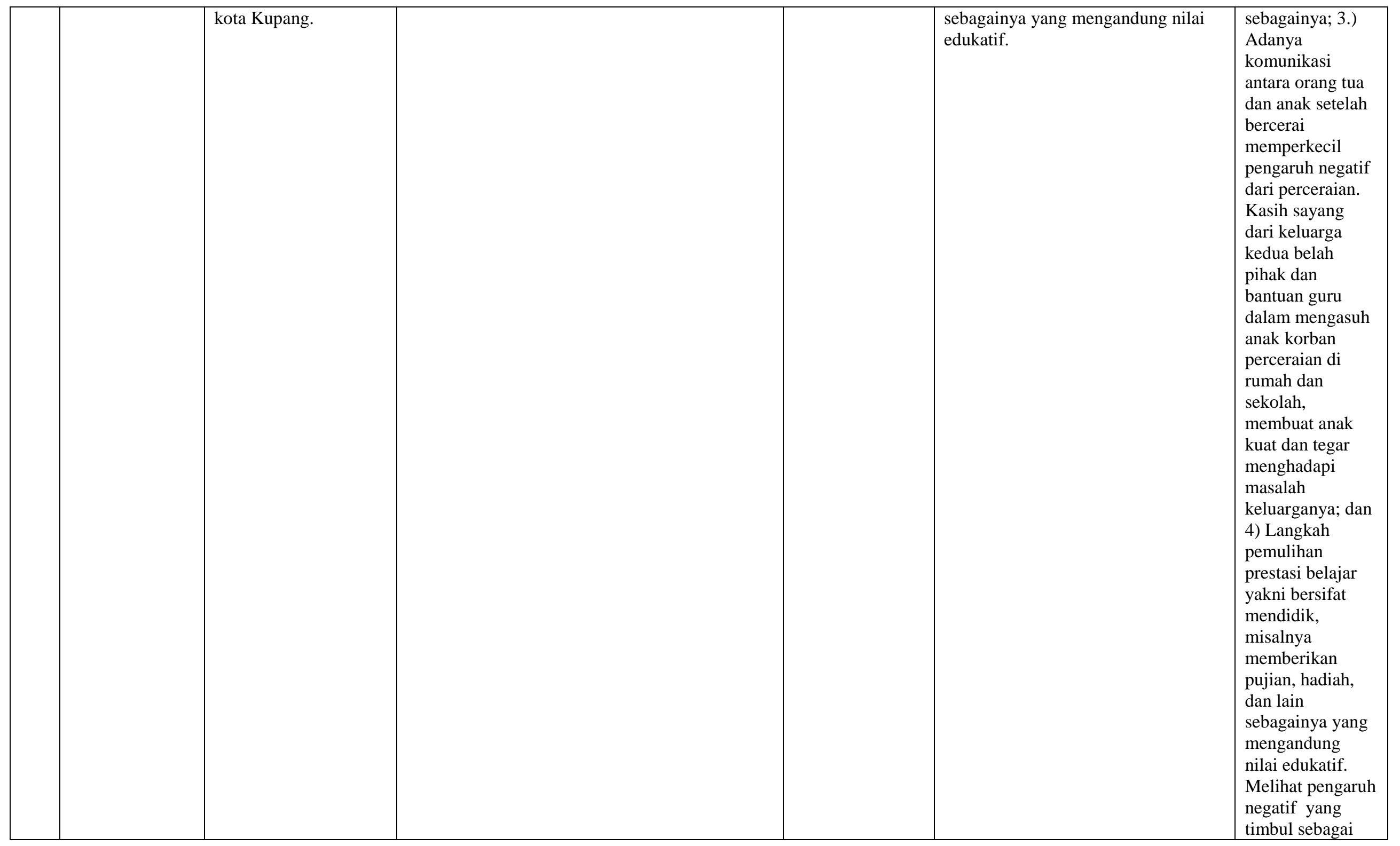




\section{REVIEW ARTICLE}

Juni 2020. Dampak Perceraian di Indonesia Systematic Literature Review

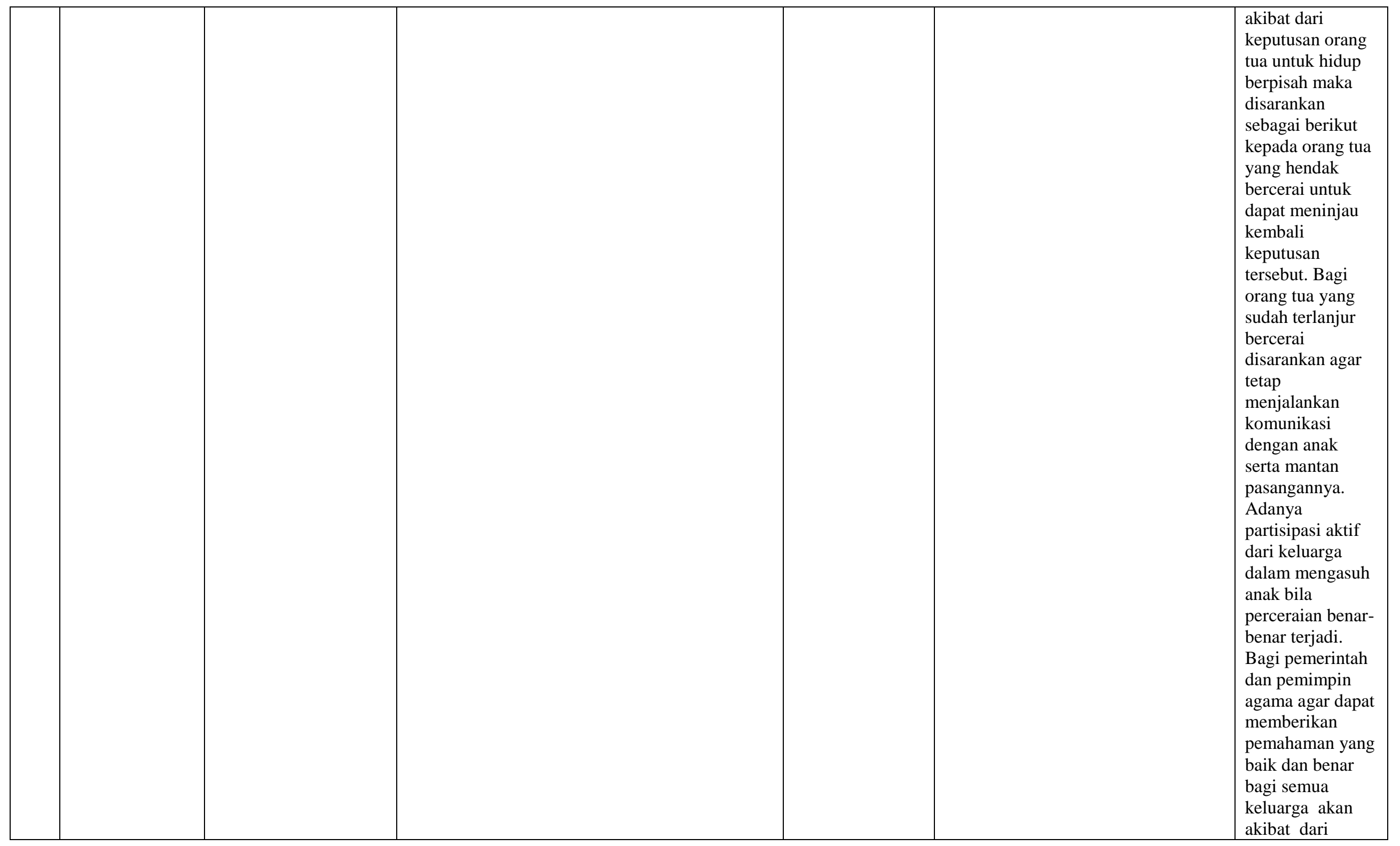




\section{REVIEW ARTICLE}

Juni 2020. Dampak Perceraian di Indonesia Systematic Literature Review

\begin{tabular}{|c|c|c|c|c|c|}
\hline & & & & & $\begin{array}{l}\text { tindakan yang } \\
\text { tidak berkenan } \\
\text { kepada anak } \\
\text { sebagai korban } \\
\text { perceraian } \\
\text { melalui diskusi } \\
\text { dan lain } \\
\text { sebagainya. }\end{array}$ \\
\hline 7 & $\begin{array}{l}\text { Ifawati Asri } \\
\text { Mawaddah } \\
(2019)\end{array}$ & $\begin{array}{l}\text { Tujuan penelitian ini } \\
\text { adaah } \\
\text { Mendeskripsikan } \\
\text { faktor penyebab } \\
\text { perceraian suami istri } \\
\text { di Desa Sulek } \\
\text { Tlogosari Bondowoso } \\
\text { dan Mendeskripsikan } \\
\text { dampak perceraian } \\
\text { orang tua terhadap } \\
\text { psikologi anak di Desa } \\
\text { Sulek Tlogosari } \\
\text { Bondowoso }\end{array}$ & $\begin{array}{l}\text { Metode yang digunakan dalam penelitian ini } \\
\text { adalah Penelitian ini menggunakan } \\
\text { pendekatan kulitatif deskriptif. Dengan jenis } \\
\text { Studi kasus. Teknik pengumpulan data dalam } \\
\text { penelitian ini wawancara mendalam, observasi, } \\
\text { dan dokumentasi. Analisis datanya } \\
\text { menggunakan kondesasi data, penyajian data, } \\
\text { dan penarikan kesimpulan, mengecek keabsahan } \\
\text { data menggunakan triangulasi data sumber, } \\
\text { metode, dan teori. }\end{array}$ & $\begin{array}{l}\text { Kesimpulan Penelitian ini adalah } \\
\text { faktor penyebab perceraian suami } \\
\text { istri di Desa Sulek Tlogosari } \\
\text { Bondowoso adalah Kekerasan verbal, } \\
\text { Ekonomi, Perselingkuhan, Kelalaian } \\
\text { (tanggung jawab), Faktor } \\
\text { Perselisihan campur tangan mertua. } \\
\text { Sedangkan dampak perceraian orang } \\
\text { tua terhadap psikologi anak di Desa } \\
\text { Sulek Tlogosari Bondowoso adalah } \\
\text { Marah (Range) atau (Qalb), Sakit- } \\
\text { sakitan (Psikomatis) atau (Nafs), } \\
\text { Kesedihan (Sorrow) atau (Qalb), dan } \\
\text { Tidak Percaya diri (Hipotimia) atau } \\
\text { (Qalb). }\end{array}$ & $\begin{array}{l}\text { Faktor penyebab } \\
\text { perceraian suami } \\
\text { istri di Desa } \\
\text { Sulek Tlogosari } \\
\text { Bondowoso } \\
\text { adalah Kekerasan } \\
\text { verbal, Ekonomi, } \\
\text { Perselingkuhan, } \\
\text { Kelalaian } \\
\text { (tanggung } \\
\text { jawab), Faktor } \\
\text { Perselisihan } \\
\text { campur tangan } \\
\text { mertua. } \\
\text { Dampak } \\
\text { perceraian orang } \\
\text { tua terhadap } \\
\text { psikologi anak di } \\
\text { Desa Sulek } \\
\text { Tlogosari } \\
\text { Bondowoso } \\
\text { adalah Marah } \\
\text { (Range) atau } \\
\text { (Qalb), Sakit- } \\
\text { sakitan } \\
\text { (Psikomatis) atau } \\
\text { (Nafs), } \\
\text { Kesedihan } \\
\text { (Sorrow) atau } \\
\text { (Qalb), dan } \\
\text { Tidak Percaya } \\
\end{array}$ \\
\hline
\end{tabular}




\section{REVIEW ARTICLE}

Juni 2020. Dampak Perceraian di Indonesia Systematic Literature Review

\begin{tabular}{|c|c|c|c|c|c|}
\hline & & & & & $\begin{array}{l}\text { diri (Hipotimia) } \\
\text { atau (Qalb). }\end{array}$ \\
\hline 8 & $\begin{array}{l}\text { Sri Endang } \\
\text { Rayung Wulan } \\
(2019)\end{array}$ & $\begin{array}{l}\text { Apakah dampak } \\
\text { negatif dari percaraian } \\
\text { terhadap anak dibawah } \\
\text { umur? }\end{array}$ & $\begin{array}{l}\text { Penelitian ini menggunakan metode } \\
\text { penelitian Normatif dengan studi literatur } \\
\text { yaitu mengkaji teori dan peraturan perundang- } \\
\text { undangan yang berhubungan dengan perceraian } \\
\text { dan dampak negatif perceraian di Indionesia. }\end{array}$ & $\begin{array}{l}\text { Kesimpulan dalam penelitian ini } \\
\text { adalah Perceraian bukan jalan keluar } \\
\text { yang baik untuk sebuah masalah di } \\
\text { dalam keluarga. Karena bukan hanya } \\
\text { suami dan istri yang menderita lahir } \\
\text { dan bathin. Tetapi juga anak-anak } \\
\text { hasil dari pernikahan tersebut. } \\
\text { Keluarga adalah sangat penting bagi } \\
\text { kehidupan anak, oleh sebab itu ayah } \\
\text { maupun ibu jangan menjadikan } \\
\text { perceraian jalan yang terbaik untuk } \\
\text { penyenyelesaian masalah } \\
\text { perkawinan. Karena perceraian } \\
\text { merupakan hal yang sangat membuat } \\
\text { menderita dan luka khusunya } \\
\text { menyangkut psikologis anak. }\end{array}$ & $\begin{array}{l}\text { Perceraian bukan } \\
\text { jalan keluar } \\
\text { yang baik untuk } \\
\text { sebuah masalah } \\
\text { di dalam } \\
\text { keluarga. Karena } \\
\text { bukan } \\
\text { hanya suami dan } \\
\text { istri yang } \\
\text { menderita lahir } \\
\text { dan bathin. } \\
\text { Tetapi } \\
\text { juga anak-anak } \\
\text { hasil dari } \\
\text { pernikahan } \\
\text { tersebut. } \\
\text { Keluarga } \\
\text { adalah sangat } \\
\text { penting bagi } \\
\text { kehidupan anak, } \\
\text { oleh sebab itu } \\
\text { ayah maupun ibu } \\
\text { jangan } \\
\text { menjadikan } \\
\text { perceraian jalan } \\
\text { yang } \\
\text { terbaik untuk } \\
\text { penyenyelesaian } \\
\text { masalah } \\
\text { perkawinan. } \\
\text { Karena } \\
\text { perceraian } \\
\text { merupakan hal } \\
\text { yang } \\
\text { sangat membuat } \\
\text { menderita dan } \\
\text { luka khusunya }\end{array}$ \\
\hline
\end{tabular}




\section{REVIEW ARTICLE}

Juni 2020. Dampak Perceraian di Indonesia Systematic Literature Review

\begin{tabular}{|c|c|c|c|c|c|c|}
\hline & & & & & & $\begin{array}{l}\text { menyangkut } \\
\text { psikologis anak. }\end{array}$ \\
\hline 9 & $\begin{array}{l}\text { Santi Muardini, } \\
\text { Alia Azmi, } \\
\text { Fatmariza } \\
(2019)\end{array}$ & $\begin{array}{l}\text { untuk menemukan } \\
\text { tentang bagaimana } \\
\text { dampak perceraian } \\
\text { pada perempuan usia } \\
\text { muda terhadap kondisi } \\
\text { sosial-ekonomi di } \\
\text { Kecamatan Pondok } \\
\text { Tinggi dan dampak } \\
\text { perceraian pada } \\
\text { perempuan usia muda } \\
\text { terhadap kondisi sosial } \\
\text { kemasyarakatan di } \\
\text { Kecamatan Pondok } \\
\text { Tinggi. }\end{array}$ & $\begin{array}{l}\text { Penelitian ini menggunakan metode kualitatif } \\
\text { deskriftif yang mengambil lokasi di Kecamatan } \\
\text { Pondok Tinggi Kota Sungai Penuh. }\end{array}$ & $\begin{array}{l}\text { Subyek dalam } \\
\text { penelitian ini } \\
\text { adalah Petugas } \\
\text { Pengadilan } \\
\text { Agama Sungai } \\
\text { Penuh, Kepala } \\
\text { KUA Kecamatan } \\
\text { Pondok Tinggi, } \\
\text { Janda Muda, } \\
\text { Keluarga Janda } \\
\text { Muda, Tokoh } \\
\text { Masyarakat, } \\
\text { Masyarakat } \\
\text { Setempat, } \\
\text { Mantan Suami } \\
\text { Janda Muda, dan } \\
\text { Laki-Laki Yang } \\
\text { Masih Lajang. }\end{array}$ & $\begin{array}{l}\text { Hasil penelitian menunjukkan } \\
\text { bahwasanya dampak perceraian pada } \\
\text { perempuan usia muda terhadap } \\
\text { kondisi sosial-ekonomi, pertama; } \\
\text { cara janda muda dalam memenuhi } \\
\text { kebutuhan ekonomi, kedua; orang } \\
\text { yang membantu janda muda dalam } \\
\text { memenuhi kebutuhan ekonomi. } \\
\text { Dampak perceraian pada perempuan } \\
\text { usia muda terhadap kondisi sosia- } \\
\text { kemasyarakatan, pertama; pandangan } \\
\text { janda muda terhadap dirinya sendiri, } \\
\text { kedua; pandangan keluarga janda } \\
\text { muda terhadap dirinya, ketiga; } \\
\text { pandangan masyarakat terhadap } \\
\text { janda muda, keempat; pandangan } \\
\text { tokoh masyarakat terhadap janda } \\
\text { muda, kelima; pandangan pemerintah } \\
\text { terhadap janda muda, keenam; } \\
\text { pandangan mantan suami terhadap } \\
\text { mantan istri (janda muda), ketujuh; } \\
\text { pandangan laki-laki yang masih } \\
\text { lajang terhadap janda muda }\end{array}$ & $\begin{array}{l}\text { Berdasarkan } \\
\text { temuan } \\
\text { penelitian dan } \\
\text { pembahasan } \\
\text { yang telah } \\
\text { dilakukan dapat } \\
\text { disimpulkan } \\
\text { bahwa dampak } \\
\text { perceraian pada } \\
\text { perempuan usia } \\
\text { muda terhadap } \\
\text { kondisi social } \\
\text { ekonomi adalah } \\
\text { janda muda } \\
\text { harus bekerja } \\
\text { untuk memenuhi } \\
\text { kebutuhan hidup } \\
\text { diri sendiri dan } \\
\text { anak serta } \\
\text { adanya bantuan } \\
\text { dari orang tua } \\
\text { untuk } \\
\text { menanmbah } \\
\text { dalam } \\
\text { memenuhi } \\
\text { kebutuhan hidup } \\
\text { janda muda } \\
\text { serta dampak } \\
\text { perceraian pada } \\
\text { perempuan usia } \\
\text { muda terhadap } \\
\text { kondisi social- } \\
\text { kemasyarakatan } \\
\text { adalah adanya } \\
\text { pandangan dari } \\
\text { masyarakatbahw } \\
\text { a janda muda }\end{array}$ \\
\hline
\end{tabular}




\section{REVIEW ARTICLE}

Juni 2020. Dampak Perceraian di Indonesia Systematic Literature Review

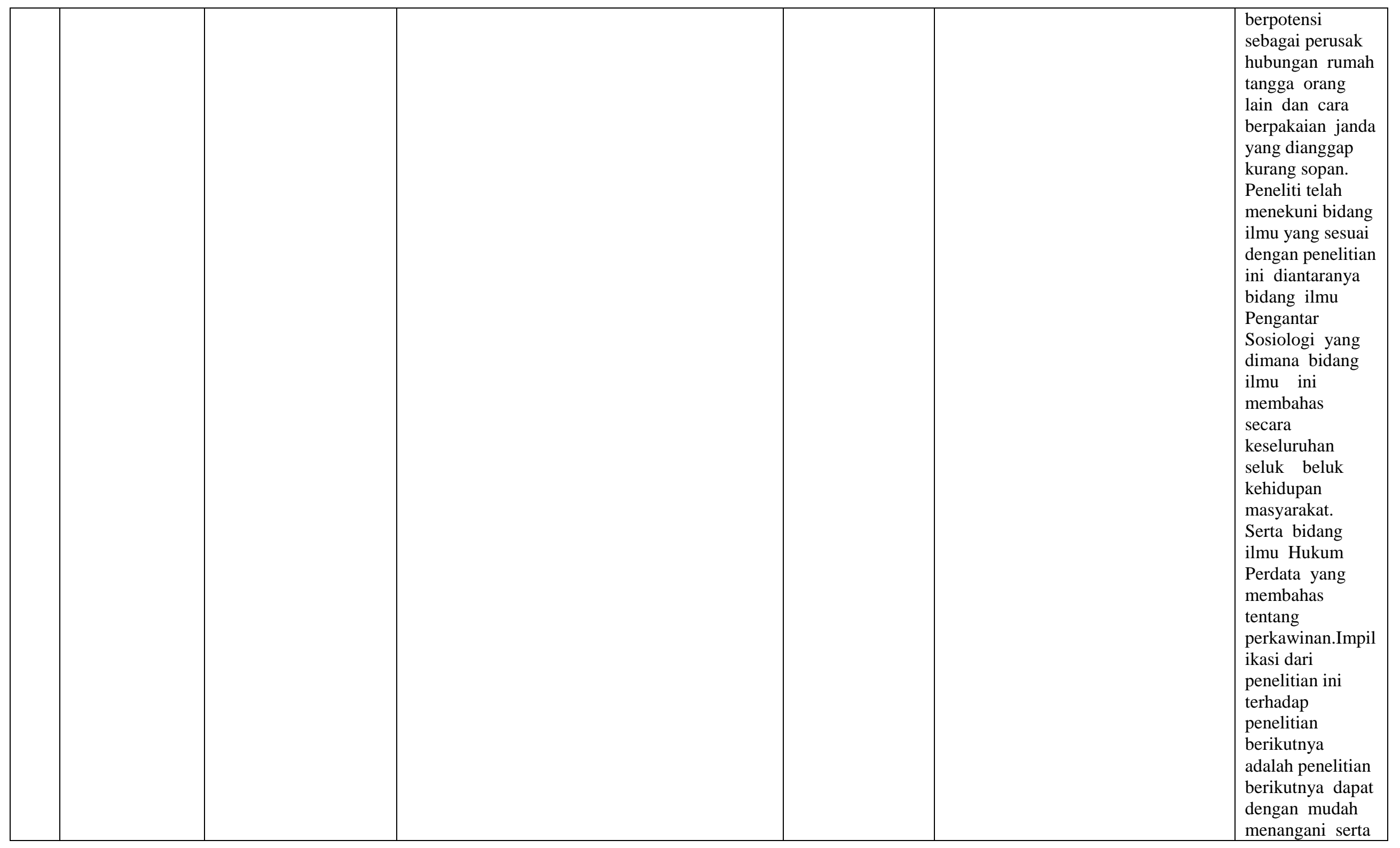




\section{REVIEW ARTICLE}

Juni 2020. Dampak Perceraian di Indonesia Systematic Literature Review

\begin{tabular}{|c|c|c|c|c|c|}
\hline & & & & & $\begin{array}{l}\text { memahami } \\
\text { tentang dampak } \\
\text { perceraian pada } \\
\text { perempuan } \\
\text { terutama yang } \\
\text { berusia } \\
\text { mudaserta } \\
\text { kegiatan-kegiatan } \\
\text { ekonomi yang } \\
\text { bisa dilakukann } \\
\text { untuk } \\
\text { menunjang } \\
\text { kehidupan para } \\
\text { janda setelah } \\
\text { terjadi } \\
\text { perceraian } \\
\text { seperti dengan } \\
\text { mengadakan } \\
\text { kegiatan PKK } \\
\text { untukmenambah } \\
\text { pemasukan para } \\
\text { janda. }\end{array}$ \\
\hline 10 & $\begin{array}{l}\text { Nailatur } \\
\text { Rosyada \& Siti } \\
\text { Mutma'inah } \\
(2019)\end{array}$ & $\begin{array}{l}\text { Penelitian ini } \\
\text { bertujuan untuk } \\
\text { mendeskripsikan } \\
\text { perkembangan } \\
\text { emosional anak dari } \\
\text { keluarga yang bercerai } \\
\text { di Yayasan Al } \\
\text { Kautsar. }\end{array}$ & $\begin{array}{l}\text { Penelitian ini menggunakan penelitian } \\
\text { kualitatif. Pengumpulan data dilakukan dengan } \\
\text { observasi dan wawancara. }\end{array}$ & $\begin{array}{l}\text { Berdasarkan penelitian menunjukkan } \\
\text { bahwa anak dari keluarga yang } \\
\text { bercerai cenderung kurang baik } \\
\text { disebabkan oleh kurang mendapat } \\
\text { kasih sayang dari kedua orangtuanya. } \\
\text { Gambaran kondisi emosi yang } \\
\text { ditunjukkan anak yaitu anak tidak } \\
\text { dapat mengendalikan diri pada saat } \\
\text { marah, yaitu sering marah tidak jelas, } \\
\text { membentak, sering menangis, dan } \\
\text { membangkang. }\end{array}$ & $\begin{array}{l}\text { Berdasarkan } \\
\text { hasil pembahasan } \\
\text { yang telah } \\
\text { dilakukan pada } \\
\text { bab } \\
\text { sebelumnya, } \\
\text { maka dapat } \\
\text { ditarik } \\
\text { kesimpulan, } \\
\text { perceraian yang } \\
\text { terjadi pada } \\
\text { orang tua subjek } \\
\text { di Yayasan Al } \\
\text { Kautsar } \\
\text { disebabkan } \\
\text { karena perbedaan } \\
\text { status sosial, dan }\end{array}$ \\
\hline
\end{tabular}




\section{REVIEW ARTICLE}

Juni 2020. Dampak Perceraian di Indonesia Systematic Literature Review

\begin{tabular}{|c|c|c|c|c|c|}
\hline & & & & & $\begin{array}{l}\text { perselingkuhan. } \\
\text { Perkembangan } \\
\text { emosi subjek } \\
\text { cenderung } \\
\text { kurang baik } \\
\text { disebabkan oleh } \\
\text { kurang } \\
\text { mendapatkan } \\
\text { kasih sayang dari } \\
\text { kedua } \\
\text { orangtuanya. } \\
\text { Gambaran } \\
\text { kondisi emosi } \\
\text { yang ditunjukkan } \\
\text { anak yaitu anak } \\
\text { tidak } \\
\text { dapat } \\
\text { mengendalikan } \\
\text { diri pada saat } \\
\text { marah, yaitu } \\
\text { sering marah } \\
\text { tidak jelas, } \\
\text { membentak, } \\
\text { sering menangis, } \\
\text { dan } \\
\text { membangkang. }\end{array}$ \\
\hline 11 & $\begin{array}{l}\text { Tesalonika } \\
\text { Liontinia } \\
\text { Crossesa, } \\
\text { Goretti Maria } \\
\text { Sindarti (2019) }\end{array}$ & $\begin{array}{l}\text { Tujuan dari penelitian } \\
\text { ini adalah } \\
\mathrm{u} \\
\text { ntuk mengetahui } \\
\text { Gambaran } \\
\text { Motivasi Belajar } \\
\text { pada Remaja yang } \\
\text { Mengalami Broken } \\
\text { Home } \\
\text { (Dampak Perceraian } \\
\text { Orang Tua) } \\
\text {. }\end{array}$ & $\begin{array}{l}\text { Penelitian ini adalah penelitian deskriptif } \\
\text { studi kasus dengan } 2 \text { subjek penelitian dan } \\
\text { dilakukan pada } \\
12 \text { Maret } 2019 . \text { Penelitian ini menggunakan } \\
\text { teknik wawancara mendalam dalam } \\
\text { pengambilan data } \\
\text { dengan instrumen yang telah dipersiapkan. } \\
\text { Data disajikan dalam bentuk narasi. }\end{array}$ & $\begin{array}{l}\text { Hasil penelitian } \\
\text { menunjukkan bahwa kedua subjek } \\
\text { penelitian (BA dan FH) sama } \\
\text { - } \\
\text { sama masih memiliki motivasi } \\
\text { belajar walaupun dalam keadaan } \\
\text { orang tua bercerai, } \\
\text { motivasi kedua subjek penelitian } \\
\text { tersebut } \\
\text { diperoleh dari dukungan orang } \\
\text { yang mereka sayangi. Rekomendasi } \\
\text { untuk penelitian selanjutnya } \\
\text { adalah peneliti hendaknya dapat }\end{array}$ & $\begin{array}{l}\text { Berdasarkan } \\
\text { hasil studi kasus } \\
\text { tentang } \\
\text { "Gambaran } \\
\text { Motivasi Belajar } \\
\text { Remaja } \\
\text { yangMengalami } \\
\text { Broken Home ( } \\
\text { DampakPerceraia } \\
\text { n Orang Tua) di } \\
\text { SMA } \\
\text { Laboratorium } \\
\text { UM Kota }\end{array}$ \\
\hline
\end{tabular}




\section{REVIEW ARTICLE}

Juni 2020. Dampak Perceraian di Indonesia Systematic Literature Review

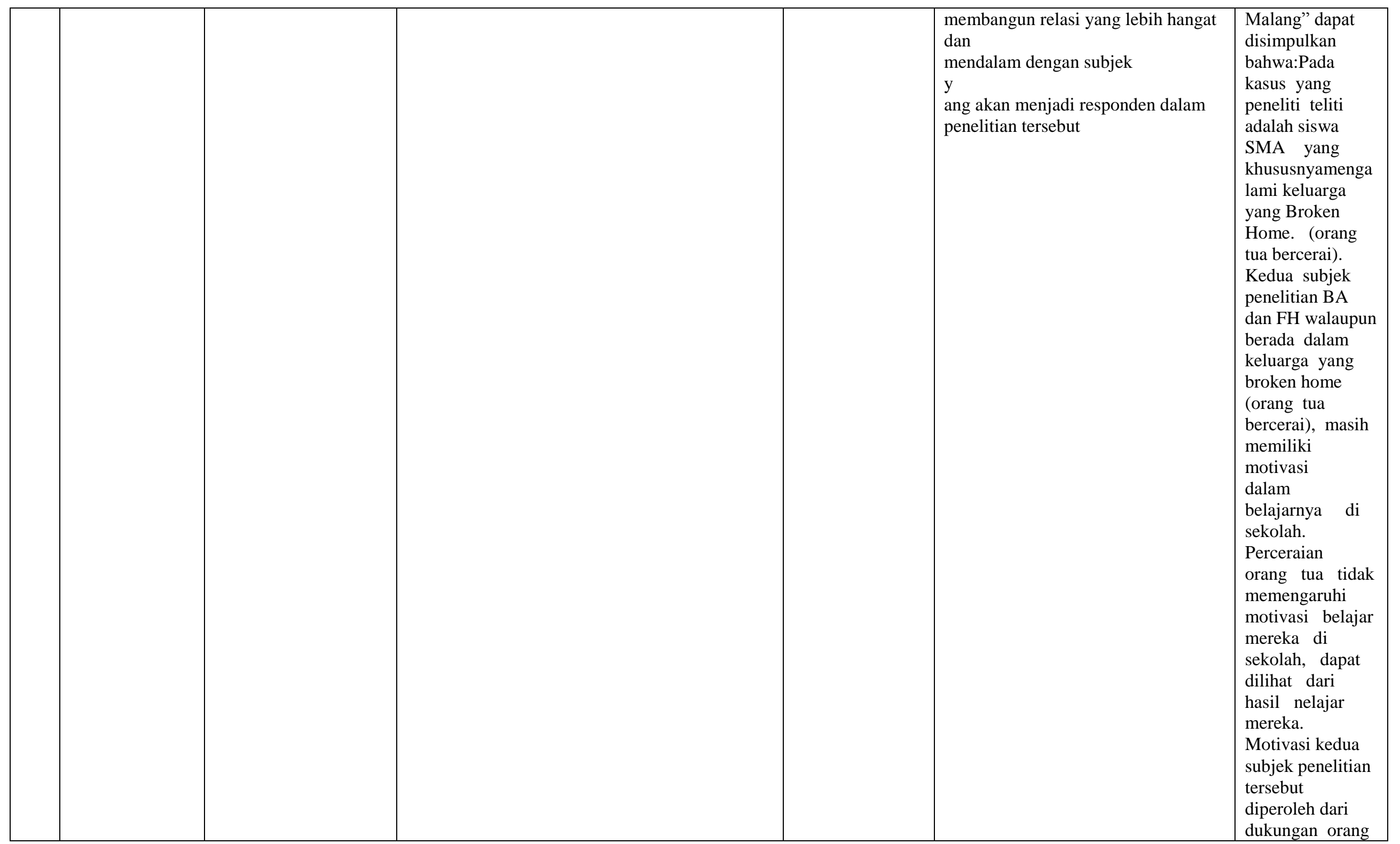




\section{REVIEW ARTICLE}

Juni 2020. Dampak Perceraian di Indonesia Systematic Literature Review

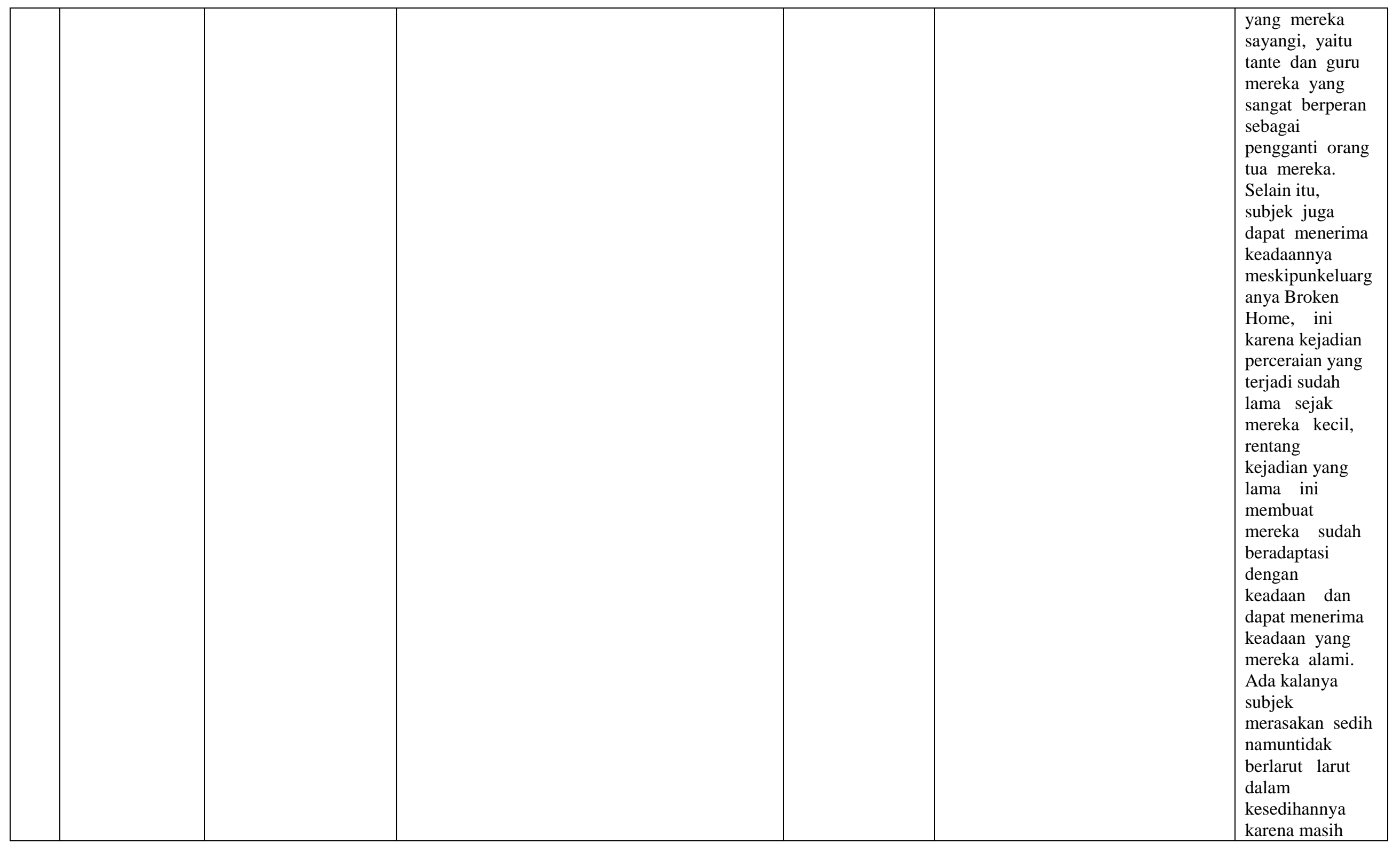


REVIEW ARTICLE

Juni 2020. Dampak Perceraian di Indonesia Systematic Literature Review

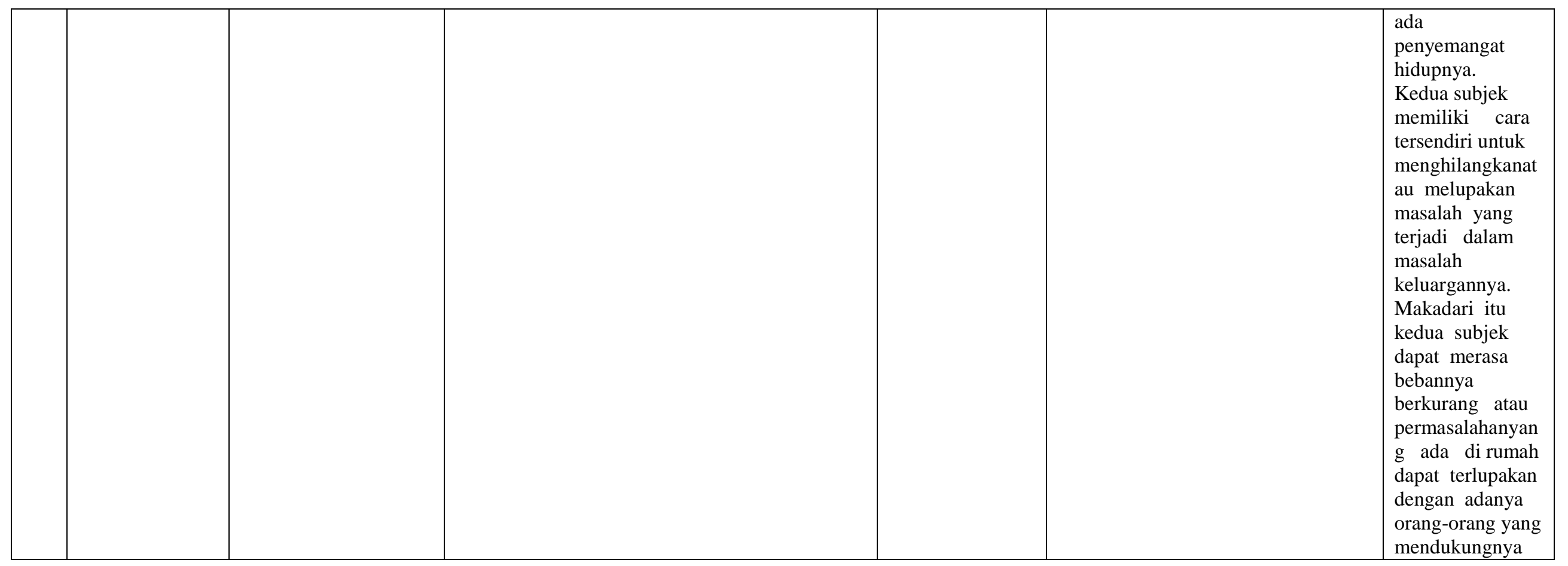




\section{Kesimpulan}

Didapatkan 11 artikel yang sesuai kriteria inklusi dan dengan critical apprasial tools dari JBI. Penyebab perceraian di Indonesia banyak faktor, dampak perceraian yang terjadi di indonesia baik pasangan, anak, dan keluarga, dan cara mengatasi dampak perceraian dengan cara motivasi, adaptasi, konseling, koping, komunikasi dan dukungan keluarga.

\section{References}

Andria Pragholapati, M. L. (2017). HUBUNGAN MASALAH KESEHATAN JIWA DENGAN STRATEGI KOPING SESEORANG YANG MENGALAMI PERCERAIAN DI KOTA BANDUNG. In Seminar Nasional Dan Workshop Keperawatan "Penguatan Profesi Keperawatan Dalam Peningkatan Pelayanan Keperawatan" Continuum of Care Dari Ketergantungan Menuju Kemandirian Hidup Yang Berkualitas.

Ariani, A. I. (2019). Dampak Perceraian Orang Tua Dalam Kehidupan Sosial Anak. Phinisi Integration Review, 2(2), 257-270

Crossesa, T. L., \& Sindarti, G. M. (2019). Gambaran Motivasi Belajar Pada Remaja Yang Mengalami Broken Home (Dampak Perceraian Orang Tua) Di SMA Laboratorium UM Kota Malang. Jurnal Pendidikan Kesehatan (e-Journal), 8(2), 131-137.

Devi, S. (2019). Dampak Perceraian di Bangkan Enrekang. Jurnal Kajian Sosial dan Budaya: Tebar Science, 3, 67-74.

Kusumawati, M. D. (2020). DAMPAK PERCERAIAN ORANG TUA TERHADAP KONDISI EMOSI ANAK USIA 6-12 TAHUN. JURNAL EDUKASI NONFORMAL, 1(2), 61-69.

Mawaddah, I. A. (2019). DAMPAK PERCERAIAN ORANG TUA TERHADAP PSIKOLOGI ANAK DI DESA SULEK TLOGOSARI BONDOWOSO. ASA, 1(1).

Mone, H. F. (2019). Dampak perceraian orangtua terhadap perkembangan psikososial dan prestasi belajar anak. Harmoni Sosial: Jurnal Pendidikan IPS, 6(2).

Muardini, S., Azmi, A., \& Fatmariza, F. (2019). DAMPAK PERCERAIAN PADA PEREMPUAN USIA MUDA DI KECAMATAN PONDOK TINGGI KOTA SUNGAI PENUH. Journal of Civic Education, 2(1), 1-11.

Pragholapati, A. (2020). Anxiety in Someone Who Has Divorce.

Pragholapati, A. (2020). Coping Strategies for Someone Divorced.

Pragholapati, A. (2020). Depression in Someone Who Has Divorce.

Pragholapati, A. (2020). Marriage and Divorce.

Pragholapati, A. (2020). Mental Health Issues Someone Who Has Divorce.

Pragholapati, A. (2020). The Role of Nurses in Divorce. 


\section{REVIEW ARTICLE}

Juni 2020. Dampak Perceraian di Indonesia Systematic Literature Review

Pragholapati, A. (2020, May 28). Anxiety in Someone Who Has Divorce. https://doi.org/10.31234/osf.io/6n4qh

Pragholapati, A. (2020, May 28). Coping Strategies for Someone Divorced. https://doi.org/10.31234/osf.io/w4zdb

Pragholapati, A. (2020, May 28). Depression in Someone Who Has Divorce. https://doi.org/10.31234/osf.io/78xhm

Pragholapati, A. (2020, May 28). Marriage and Divorce. https://doi.org/10.31234/osf.io/sx9yb

Pragholapati, A. (2020, May 28). Mental Health Issues Someone Who Has Divorce. https://doi.org/10.31234/osf.io/d3y4j

Pragholapati, A. (2020, May 28). The Role of Nurses in Divorce. https://doi.org/10.31234/osf.io/bxs3v

Rahim, F., \& Fitriawati, H. (2019). Dampak Perceraian terhadap Kelangsungan Pendidikan Anak di Pangkung Buluh, Jembrana. An-Nahdlah, 5(2), 1-15.

Ramadhani, P. E., \& Krisnani, H. (2019). ANALISIS DAMPAK PERCERAIAN ORANG TUA TERHADAP ANAK REMAJA. Focus: Jurnal Pekerjaan Sosial, 2(1), 109-119.

Rosyada, N., \& Mutma'inah, S. (2019). DAMPAK PERCERAIAN TERHADAP PERKEMBANGAN EMOSI ANAK USIA 3-5 TAHUN DI YAYASAN AL KAUTSAR SUKOHARJO. Academica: Journal of Multidisciplinary Studies, 3(2), 279-290.

Wulan, S. E. R. (2019). PERCERAIAN YANG MENGAKIBATKAN DAMPAK NEGATIF TERHADAP ANAK KHUSUSNYA ANAK DIBAWAH UMUR. Journal de Facto, 6(1). 